\title{
Dijital Ortamda Marka İmaj Transferi ve İtibar Göstergeleri: Rolex-Roger Federer Örneği
}

\section{Brand Image Transfer and Reputation Indicators in Digital Media: The Case of Rolex- Roger Federer}

\author{
Sevinç Koçak, ${ }^{\mathrm{a}}$ Merve Çelik Varol ${ }^{\mathrm{b}}$ Erdem Varol $^{\mathrm{c}}$

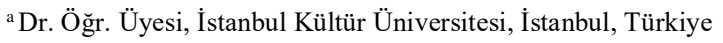 \\ sevinc_kocak@hotmail.com \\ ORCID: 0000-0002-9503-3379 \\ b Doktora Öğrencisi, İstanbul Üniversitesi, İstanbul, Türkiye \\ mervecvarol@gmail.com \\ ORCID: 0000-0002-0698-929X \\ C Arş. Gör. Marmara Üniversitesi, İstanbul, Türkiye \\ erdem.varol@marmara.edu.tr \\ ORCID: 0000-0003-3940-2122
}

\section{MAKALE BÍLGİSi}

\section{Makale Geçmişi:}

Başvuru tarihi: 01.10.2020

Düzeltme tarihi: 07.12.2020

Kabul tarihi: 21.12.2020

\section{Anahtar Kelimeler:}

Halkla Ilisşkiler

Pazarlama İletişimi

Itibar Yönetimi

Imaj Transferi

Göstergebilim

\section{ÖZ}

İtibar kavramının tüm iletişim çalışmalarında stratejik bir unsur olarak ele alınmasıyla birlikte, markaların pazarlama iletişimi çalışmalarındaki imaja yönelik reklamlarında da karşımıza çıkması kaçınılmazdır. Küresel markalar, konumlandırmaları gereği, kendi itibarlarını ve imajlarını oluştururken, uyguladıkları iletişim stratejisiyle doğru orantılı olarak çeşitli kavram, kişi ve göstergelerden yararlanmaktadırlar. $\mathrm{Bu}$ bağlamda, bir yandan tüketiciler nezdinde söz konusu imaja ve itibara yönelik unsurların ne derece önemli olduğunun belirlenmesine yönelik araştırmalar yapmak, diğer yandan bu araştırmaların sonuçlarına göre göstergeleri kullanarak pazarlama ve reklam çalışmalarını yapmak marka iletişiminde önemli olmaktadır. Marka iletişiminde ünlülerin kullanılması da oldukça yaygın bir itibar çalışması ve imaj transferi unsurudur. Bu çalışmada, Rolex markasının dijital, elektronik ve basılı mecralarda Roger Federer'i kullanması örneği, markaya atfedilen itibar ve imaj transferi ipuçları açısından, hem tüketicilere yönelik bir anket çalışması yapılarak hem de dijital ve basılı mecralarda yer alan reklamlardaki göstergelerin Roland Barthes'ın "düzanlam" ve "yananlam” teorisi kullanılarak incelenmesi yapılmıştır. Böylece, reklamlarda ve marka iletişiminde ünlü kullanımı göstergelerinin tüketicilere yansıması ve itibar kavramına yönelik unsurlar hep birlikte ele alınarak, günümüz iletişim çalışmalarının komplike yapısı ortaya konulmaktadır.

\section{ARTICLE INFO}

\section{Article history:}

Received: 01.10.2020

Received in revised form: 07.12.2020

Accepted: 21.12 .2020

\section{Keywords:}

\section{Public Relations}

Marketing Communication

Reputation Management

Image Transfer

Semiotics

\begin{abstract}
While the concept of reputation is considered as a strategic element in all communication activities, it is inevitable that brands will also appear in image-oriented advertising in marketing communication activities. Due to their positioning, global brands make use of various concepts, persons and indicators in direct proportion to the communication strategy they implement while creating their own reputation and image. In this context, on the one hand, it is important to make research with consumers for determining the impact of the elements related to the image and reputation, and on the other hand, it is important also to create the marketing and advertising strategies by using the results of these research. The using of celebrities in brand communication is also a common component of reputation function and image transfer. This study is traying to put forward the reputation and image transfer clues attributed to the brand by studying on the example of Rolex brand with Roger Federer advertisements and also a survey conducted for consumers and the indicators. Advertisements are examined by using Roland Barthes' "denotation" and "connotation" theory. Thus, the reflection of the celebrities and their indicators in the advertisements and brand communication is explaining to the consumers by using the elements related to the concept of reputation are handled together and the complex structure of today's communication studies is revealed.
\end{abstract}

\section{Atıf Bilgisi / Reference Information}

Koçak, S., Çelik Varol, M., Varol, E. (2020). Dijital Ortamda Marka İmaj Transferi ve İtibar Göstergeleri: Rolex-Roger Federer Örneği• Uluslararası Kültürel ve Sosyal Araştırmalar Dergisi (UKSAD), 6 (2), Kış, s.597-625. 


\section{Giriş}

Modern toplumun giderek artan rekabet koşullarında, markalar sadece ürün, hizmet, işlev, nitelik ve kalite boyutları için değil, aynı zamanda kurumsal imaj ve kurumsal itibar alanlarında da rekabet etmektedir. İmaj kavramı incelendiğinde "pazarlama", "halkla ilişkiler", "çevre ve yönetim” gibi sayısız disiplinin de iç içe geçtiği görülmektedir. Marka imajı, bir tüketicinin bir markayla ilgili deneyimlerine dayanarak markaya karşı düşündüğü veya hissettiği yoldur. Bu deneyimin iyi veya kötü olup olmadığına bağlı olarak marka imajı belirlenmektedir. Başka bir deyişle, marka imajı marka itibarını etkilemektedir.

Günümüzde markaların, tüketicilerin ürün ya da hizmetler ile ilgili olumsuz deneyimlerine yönelik markanın algısını değiştirmek adına daha çok çalışmaları gerektiği aşikardır. Tam tersi durumda tüketicilerin markaya yönelik olumlu deneyimleri söz konusu olduğunda, marka için müşteri sadakati ve güçlü bir rekabet avantajı oluşturma olasılığ 1 daha yüksek görülmektedir. Denilebilir ki, bir kurumun sahip olabileceği en değerli varlık, tüketicilerin ürün, hizmet ve marka adı görüldüğünde veya duyulduğunda akla gelen maddi olmayan değer algılarıdır.

"Marka imajı" ve "marka itibarı" kavramları her ne kadar birbirleri ile yakından ilişkili olsa da söz konusu iki kavram birbirinden farklıdır. Günümüzde kurumlar açısından söz konusu iki kavram arasındaki farkı anlamak, tüketiciler tarafından nasıl algılandığına odaklanmalarına ve önceliklendirmelerine yardımcı olabilmektedir. Bu bağlamda, kurumların tüketiciler açısından söz konusu imaja ve itibara yönelik unsurların ne derece önemli olduğunun belirlenmesine yönelik araştırmalar yapması, diğer yandan bu araştırmaların sonuçlarına göre göstergeleri kullanarak pazarlama ve reklam çalışmalarını uygulaması marka iletişiminde önemli görülmektedir. Günümüzde yapılan marka çalışmalarına bakıldığında ünlü kullanımının da oldukça yaygın bir itibar çalışması ve imaj transferi unsuru olduğu bilinmektedir. Bu çalışmanın amacı, Rolex markasının dijital, elektronik ve basılı mecralarda Roger Federer'i kullanması örneğinden yola çıkarak, markaya atfedilen itibar ve imaj transferi açısından, hem tüketicilere yönelik bir anket çalışması yapmak hem de dijital ve basılı mecralarda yer alan reklamlardaki göstergelerin Roland Barthes'1n "düzanlam” ve "yananlam” teorisini kullanarak incelenmesidir. Bu noktadan hareketle, bu çalışmada reklamlarda ve marka iletişiminde ünlü kullanımı göstergelerinin tüketicilere yansıması ve itibar kavramına yönelik unsurlar ele alınarak, günümüz iletişim çalışmalarının komplike yapısı ortaya konulmaktadır.

\section{Tüketiciler Açısından Marka, İmaj ve İtibar Kavramlarının Önemi}

Günümüzde kurumlar markalarına odaklanarak, kendilerini tüketici istek ve ihtiyaçlarına göre geliştirdiklerinde, güçlü bir rekabetçi pozisyon elde etmektedir. Buna ek olarak, kurumlar markalarının olumlu imajını tüketicinin hayal gücünde oluşturmaya çalıştıklarında, markaların pozitif bir değer yaratması ve tüketicilerin seçim sürecine yardımcı olmaları anlamına gelmektedir. Hem gün be gün artan rekabet ortamında var olmak için hem de ürün ve hizmetlerinin tüketiciler tarafindan seçilmesini sağlamak için kurumların yenilikçi ve yaratıcı olmaları gerekmektedir. Bu bağlamda, yenilikçi ve yaratıcı olmak, söz konusu ürünlerin ve hizmetlerin markalaştırılması, ürün ve hizmetlere dikkat çekmek ve bu ürünlerin toplanmasını ve yeniden seçilmesini sağlamak için kurumların benimseyebileceği stratejilerden biridir. Söz konusu stratejileri kullanmak marka imajı için de oldukça önemli görülmektedir. Marka Derneği tarafindan tüketicinin zihnine getirilen bir marka olarak tanımlanabilen marka imajı (Keller, 1993), tüketicinin markayla ilgili düşünceleri ve duyguları olarak da tanımlanabilmektedir. Aaker'in (1991) de belirttiği gibi, marka imajının tüketiciler için oldukça önemli olduğu görülmektedir. Bearden \& Etzel (1982) ve Park \& Arinivasan (1994)' a göre ise marka imajı belirli bir ürün sınıflandırmasının benzersizliğiyle yakından ilişkilidir. Hsieh \& Li'ye (2008) göre, güçlü marka imajı, rekabet edilen marka üzerinde belirli bir markanın üstün mesajlarını yaratmaktadır.

İmaj, herhangi bir varlığın görselleştirilmiş yüzünün zihinsel etkinlikleri anlamına gelen 'simge' kelimesinin türetilmiştir. Bireyin marka varlığını hatırlamasına ve tanımasına yardımcı olmak için kişinin zihninde yaratılan bir kişi, kurum, ürün veya durum hakkındaki izlenimleri ifade etmektedir. İmaj, 
bireylerin satın alma davranışlarına rehberlik etme niteliğine sahiptir ve daha geniş bir anlatımla, pozitif, negatif ve nötr gibi sıfatlar kullanılarak tanımlanabilmektedir. Günlük yaşamda imaj bireyle, işletmeler, şehirler veya ülkeler hakkında bilinçli veya bilinçsizce yaratılan olumlu veya olumsuz algıları ifade etmektedir (Akdu, 2017:67).

Tüketiciler ürün ve markalar hakkında daha bilgili hale geldikçe -çalışanların çalışma ortamı, sosyal sorumluluk ve toplum katılımı gibi- marka imajı kavramı da giderek önem kazanmaktadır. Marka imajı, tüketicilerin belleğinde bir markaya bağlı bilgi ve bir marka görüntü öğesi olarak kabul edilmektedir.

Dobni \& Zinkhan (1990) marka imajını ürünün tüketicideki zihinsel resmi olarak tanımlamakta ve marka imajı tüketicinin zihni ile bağlantılı bir markanın temsili olarak görülmektedir. Bir başka deyişle marka imajı, Keller'ın (1993) da belirttiği gibi markalar tarafindan tüketicilerin zihninde yaratılan bir dizi alg1 olarak tanımlanmaktadır.

Marka imajı kavramı Low \& Lamb (2000) tarafından "tüketicilerin belirli markalara bağlı olduğu gerekçeli veya duygusal algılamalar” olarak tanımlamaktadır. Bu nedenle, marka imajının somut kalite özellikleri üzerinde önemli bir rol oynadığı aşikardır. Markanın imajı, tüketiciler tarafından algılanan kaliteye etki ettiğinde, tüketici seçimini de etkileyebildiği söylenebilmektedir.

Denilebilir ki, marka imajı, herhangi bir kurumun ulaşmak istediği hedef kitlenin zihninde ortaya çıkan resimdir. Farklı bir deyişle; marka imajı, belirli bir kuruluşla ilişkili sıfatlarla ilgili olarak hedef kitle zihninde var olan tüm kararların birikimidir. Buna ek olarak, kurumların tüketici tarafindan tanınması ve algılanması ile ilgili tüm analizlerin bir derlemesini ifade etmektedir. Bir başka deyişle, tüm bu analizler marka imajının makyajını yapmaktadır.

Pazarlama, strateji ve iletişim disiplinleri ile ilgilenen araştırmacılar, marka itibarı kavramını marka imajı ile ilişkilendirerek açıklamaktadırlar. Marka imajını bir kurumun çevresinin dışındaki varlıklar üzerinde yarattığı etki olarak ele alıp; başka bir deyişle, marka imajını, herhangi bir kurumun kapsamı dışındaki insanların zihnindeki düşünce ve inançlar olarak tanımlamaktadırlar (Hatch ve Schultz, 1997:359).

Marka imajı sadece inançlar, düşünceler, izlenimler ile ilgili değil aynı zamanda ürün ve hizmetler, gelenekler, ideoloji ve kalite ile ilgili bir kavram olarak görülmektedir. İmaj, bir kurumun dış paydaşlarına karşı kısa vadeli algıları olarak kabul edilirken, marka imajı daha uzun vadede elde dilen tüketicilerin zihnindeki ürün ya da hizmetler ile ilgili düşünceleri olarak tanımlanabilmektedir.

Rekabeti sürekli körükleyen, ürünlerin ömrünü kısaltan ve pazarda yer alan ürün ve hizmetlerin arasındaki benzerlikleri çoğaltan küreselleşmenin bir sonucu olarak, tüketiciler seçim yapmak için belirli standartlar ararken, kurumlar ise başarıya ulaşma yolunda ek kurumsal değerler elde etmek için belirli standartlar yaratmaya çalışmaktadır. Marka itibarı da kurumlar nezdinde kazanılmaya çalışılan kavramlardan biridir.

Marka imajı ile marka itibarı yakından ilişkili olan zaman zaman birbirleri yerine kullanılsalar da farklı tanımlamalara ve anlamlara sahip olan kavramlardır. Marka itibarı, markaların "güvenilir olma", "sayg1 duyulma", "saygın olma", "finansal açıdan güçlü olma" gibi kavramlarla ilişkilidir. İtibar ve onay kurumlar için kritik bir konu olarak görüldüğünden, tüm tüketicilerin beklentileri bu kavram ile eşdeğer olarak ele alınmaktadır.

Aynı durum kurumlar için de söz konusu olabilmektedir. Kurumlar, potansiyel tüketicilerini arttırarak pazarda var olmaya devam etmek ve karlarını en üst düzeye çıkarmak istemekte, tüketiciler üzerinde iyi bir izlenim bırakmak hayati önem taşımaktadır (Karaköse, 2007:3).

Tüketiciler üzerinde olumlu izlenimler bırakmayı arzulayan markalar, bir dizi pazarlama faaliyetinin sonucu olarak imaj transferi kavramı ile karşımıza çıkmaktadır. McCracken'in (1989) başarılı olmuş bir marka imaj transferinin nasıl gerçekleştiğine dair yaptı̆̆ 1 tanım dikkat çekmektedir. Söz konusu transfer "anlam aktarımı" olarak kabul edilmektedir. Tiger Woods'un "üstünlük”, "gençlik”, "cazibeli olması" gibi bazı anlamları Nike markasına aktarması örnek olarak gösterilebilmektedir. Markaların ünlü 
kullanımlarının yanı sıra imajın, marka uzantıları ve ortak markalaşma (bazen kompozit markalaşma olarak da adlandırılmaktadır) aracılığıyla bir markadan diğer markaya aktarıldığı da görülmektedir.

Aaker ve Keller'ın (1990) da belirttiği gibi, marka uzantıları aracılığıyla temel markadan yeni markaya anlam aktarımları söz konusu olabilmektedir. Virgin'in, seyahatten "kola"ya kadar değişen pazarlarda "gençlik" ve "eğlence" imajını aktarmaya çalışması buna örnek gösterilebilmektedir. Ortak marka, marka isimlerini tanıtan iki kurumu temsil etmektedir. Söz konusu Virgin markası, yeni ve farklı bir ürünle ilgili ortaya çıkmakta (örneğin, Mcvities tarafından pişirilen Galaxy kek çubukları) ya da sadece mevcut çekirdek markaların reklamını yapabilmektedir (örneğin, Kraft ve Nickelodeon, Çocuk TV kanalı). Bu tür ittifakların mantığı ise, yeni markaya ya da çekirdek markaya faydalı olabilecek imajın aktarılması olarak düşünülmektedir.

Güçlü bir marka imajı, doğru bir biçimde gerçekleştirilen marka imaj transferi kurumun devamlılı̆̆ ve sürekliliği açısından olumlu görülmekte, marka itibarına da olumlu katkılar sağlanmasını mümkün kılmaktadır.

Kurumsal İtibar $=$ İmaj Toplamı $=($ Performans ve Davranışlar $)+$ İletişim şeklinde formüle edilebilir (Koçak, 2018:2). Bu formüle dayalı olarak denilebilir ki, bir markanın gerçekleştirdiği tüm çalışmalar itibar algısına etki etmektedir. Kurumsal itibar kavramının yaratıcısı ve Fortune 500 dergisinin itibar listesinin oluşmasına kaynaklık eden James Fombrun'un 7 kriteri Kurumsal Çekicilik, Ürünler ve Hizmetler, Finansal Performans, Vizyon ve Liderlik, Çalışma Ortamı ve Sosyal Sorumluluk başlıklarında toplanır (Koçak, 2018:2). Bu kriterlerin her biri birbiriyle etkileşim halindedirler ve toplu olarak itibar algısını oluştururlar. Kurumsal itibarın sayılan tüm bileşenlerinin oluşturduğu itibar tüketici nezdinde marka itibarını oluşturur.

İtibar, bireylerin belirli bir durum ve belirli bir güvenilirlik seviyesi üzerinde değerlendirmesini gösteren soyut bir değer olarak kabul edilmektedir. İtibar, güvenilir olma anlamında kullanılmakta ve uzun vadeli tutarlı davranışlar sonrasında kazanılabilmektedir. Diğer taraftan uzun vadede inşa edilen itibar kavramı kolayca kaybedilebilmektedir. Özellikle başarılı olmak, kurumsallaşmak ve kâr elde etmek, kurumların itibarlarını kazanmaları için kritik adımlar olarak görülmektedir. Müşterilerinin gözünde markalar için itibar en az ürün satışları kadar kıymetlidir.

Marka itibarı, rekabet gücü yüksek bir ortamda kurumların saygınlığını en üst seviyeye taşımak için gerekli olan özelliklerden biridir. İtibar kavramı, hissedar gruplarının görüşlerinin toplamını ifade etmektedir. Başka bir perspektifte kurumsal itibar, kolektif imajın ifadesi ile eşittir. Genel bir bakış açısıyla itibar, kurumların daha önceki eylemlerinin etkisidir (Yaşlıŏlu, 2012:2).

Bir kurumun sürdürülebilirliğinin en güçlü göstergelerinden biri olan marka itibarı, bir kurumun nasıl algılandığını gösteren soyut bir kavram olarak karşımıza çıkmaktadır. Yüksek itibara sahip olan kurumlar tüketicilerin, yatırımcıların, tedarikçilerin ve çalışanların ilk tercihi haline gelerek önemli faydalar sağlamaktadır. Yüksek itibar, marka değerini artırabilmekte, satın alma davranışını artırabilmekte ve daha fazla verim kazandırabilmektedir (Karaköse, 2007:42).

Sözgelimi, kurumsal itibarın en önemli unsurlarından biri, herhangi bir kurumun tüm ortaklarını ağırladığı ve kitleler tarafından erişilmesine izin veren yüzünü yansitan bir marka olduğu bilinmektedir. Bu bağlamda marka, bir işletmenin itibarını düşürebilen veya yükseltebilen bir faktör olarak karşımıza çıkmaktadır. Marka, tüketicilerin belirli bir ürünü muadillerinden ayırt etmelerine yardımcı olabilecek bir isim, logo, işaret ve semboldür. Başka bir tanım ise marka kavramının bir işaret olmanın yanı sıra, tüketicilerin bir işletmenin sunduğu bir ürün ve hizmetler hakkında tuttuğu duygu ve düşüncelerin toplamıyla ilgili olduğunu savunmaktadır.

Marka, kurumların daha popüler olmasına katkıda bulunarak, kurumsal imajı güvence altına alma, rekabet gücünü artırma, işe değer katma ve çalışan motivasyonunu arttırma gibi birtakım avantajlara sahiptir (Yaşlığlu, 2012:35). 
Denilebilir ki, marka değerleri kurum kültürü ve kurum değerleri ile uyumlu olduğunda, yenilikçi, ayrılmaz ve güvenilir olarak algılanacaktır. Güçlü bir markanın güvenilirliğini ve temsil ettiği artı değerleri tespit etme konusunda farkındalık ve itibarın yükseldiği bilinmektedir. Söz konusu durum marka ve marka imajı arasındaki bağlantıya da bağlıdır. Kurum kültürü ile ilişkili bir imajın tadını çıkarmak için başarılı bir markanın da gerekli olduğu kabul edilmektedir (Hatch \& Schultz, 1997:11).

Olumlu bir marka itibarının, tüketicileri bu özel markaya sadakati sürdürmeye, şirketin ürün ve hizmetlerini tercih etmeye motive edeceği ileri sürülmektedir. Marka itibarının aksine, marka imajı belirli bir marka üzerindeki tüketicilerin algılarını yansıtmaktadır. Ürün veya hizmet markasının imajı, müşterilerin ve tüketicilerin bu marka adına yürütülen pazarlama faaliyetlerinin bir etkisi olarak zihinlerinde oluşturduğu fikrini ifade etmektedir (Shockley-Zalabak, P. Ellis K. ve G. Winograd 2000:4).

Denilebilir ki, marka itibarı, markanın vaadini sürdürülebilir bir şekilde sunabileceğinin kanıtıdır. Bu bağlamda, marka imajının ve marka itibarının ne kadar önemli olduğu görülmektedir ve kurumlar açısından her iki kavramı da geliştirmeye dikkat etmek gerekmektedir. Bununla birlikte, marka itibarı kurum geliştikçe daha fazla dikkat edilecek bir kavram olacağından tüketicilerin nezdinde marka imajına odaklanmak önemli görülmektedir.

Marka imajı, 20. yüzyıldan beri marka sermayesinin oluşturulmasındaki önemi nedeniyle yoğun bir şekilde incelenmektedir. Giderek artan rekabet koşullarında, kurumların tüketici davranışları hakkında daha derin bir anlayışa sahip olmaları ve etkili pazarlama stratejileri geliştirmek için tüketicileri marka hakkında eğitmeleri gerekmektedir.

Keller (1993) tarafından ortaya koyulan “Tüketici Tabanlı Marka Eşitliği” marka hakkında farklı derecelerde bilgiye sahip tüketicilerin markalaşma kampanyasındaki çeşitli tepkiler ifade etmektedir. Bir başka deyişle, marka imajı ve marka bilinirliği, marka öz sermayesinin temeli ve kaynakları olarak kabul edilmektedir. Keller (1993) ' e göre, benzersiz ve güçlü marka ilişkisini tüketicilerin marka hakkındaki tecrübeleri ve pazarlama kampanyalarıyla birleştirerek pozitif marka imajı oluşturulabilmektedir. Bu bağlamda, marka bilgisi tüketiciler markalaşma kampanyasına olumlu yanıt vermeden önce inşa edilmekte ve anlaşılmaktadır.

Keller (1993), Lassar ve ark. (1995), marka öz sermayesinin tüketicilerin markaya olan güveninden geldiği görüşünü savunmaktadır. Buna göre; tüketicilerin markaya duydukları güven arttıkça, bunun için yüksek bir fiyat ödemeye istekli olma olasılıkları da artmaktadır. Spesifik olarak, bu güven beş önemli unsurdankaynaklanmaktadır: Birincisi, markanın işlevlerini tasarlandığı gibi yerine getirmesidir; ikincisi, sosyal imajdır, ki markayı satın alma veya sahip olma ile ilişkilidir; üçüncüsü, tüketicilerin marka ile tanınması ve duygusal bağının kurulmasıdır; dördüncüsü, marka ile tüketici arasındaki denge, değer ve işlevlerdir; beşincisi ise, tüketicilerin markaya güven duymalarıdır.

Markaların çoğalması, rekabetin artmasıyla birlikte, tüketiciler satın alma kararlarını büyük ölçüde ürünün kendisinden ziyade marka imajına bağlı olarak yapmaktadır. Sözgelimi, marka imajı tüketicilerin benlik kavramıyla tutarlı olduğunda, tüketiciler buna uygun ürünü ve hizmeti tercih edecektir. Benlik kavramı teorisine göre, kişinin benlik kavramı, yetenekler, özellikler, eksiklikler, görünüm ve kişilik gibi unsurları içeren bir alg1 topluluğu olarak kabul edilmektedir. Pazarlamacılar için, markalar arasındaki tutarlılığı incelemek; imaj ve tüketicilerin benlik kavramını irdelemek çok önemli görülmektedir. Çünkü tüketiciler farklı sosyal bağlamda çeşitli benlik kavramlarını ifade edebilmektedir. Ancak bağlam ne olursa olsun, tüketiciler marka imajını kendi benlik kavramına uygun olduğu sürece daha kolay tercih etmektedir.

Markalar, tüketicilerde, haz, doyum, imaj ve beklenti yaratabilmek için çeşitli simgeler, semboller, tarzlar ve mitlerden kısaca göstergelerden yararlanmaktadırlar. Yaşantımızda bizi kuşatan çeşitli nesnelerin, görsellerin, işaretlerin ve sembollerin hayatı anlamlandırmak üzere çeşitli göndermelerde bulunmasını inceleyen bir bilim dalı olan Semioloji, temel özellikleri Charles Sanders Peirce ve dilbilimci Ferdinand de Saussure tarafindan belirlenen bir disiplini kapsar. Bir gösterge, kendisinden başka bir şeye gönderme yapan, duyularımızla kavrayabileceğimiz fiziksel bir şeydir ve varlığı, kullanıcıların onu bir gösterge 
olarak kabul etmelerine bağlıdır (Fiske, 2003:63). Gösterge terimi dilbilim alanında bir gösterilen ya da kavram ile bir gösteren ya da işitim imgesi arasındaki birleşimden doğan öğeyi belirtmek için kullanılır; daha genel olarak da «kendi dışında bir şey gösteren öğe» anlamına gelir (Barthes, 1979:9).

Şekil 1: Pierce'in Anlam Öğeleri

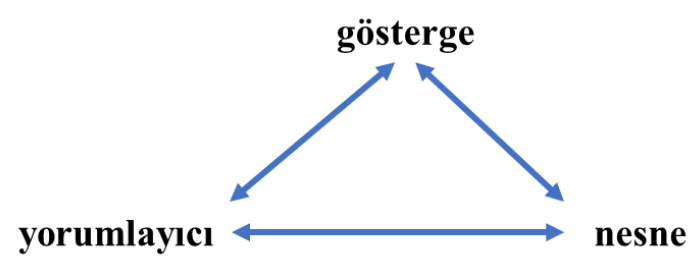

Kaynak: Fiske, 2003, 64.

Peirce (ile Ogden ve Richards) göstergeyi, göstergenin gönderme yaptı̆̆ı şeyi ve göstergenin kullanıcılarını bir üçgenin üç köşesi olarak görür (Fiske, 2003:64). Bir gösterge her bir yorumlayıcı tarafından başka bir anlam yerine konulabilecek bir şeydir. Bu nedenle yorumlayıcıların, göstergenin kendisinin ve yüklenilen anlamın içeriği içerisinde bulunulan kültür, eğitim, sosyo-ekonomik statü ve diğer pek çok çevresel ve kişisel özelliklere göre değişim gösterir. Her bir göstergenin anlamlandırma sürecindeki gönderme simge ile doğrudan ilgilidir. F. de Sassure anlamlandırma sürecini aşağıdaki dizimde anlatıldığg ş̧ekilde izah eder (Fiske, 2003:67).

Şekil 2: F. de Sassure'un Anlam Öğeleri

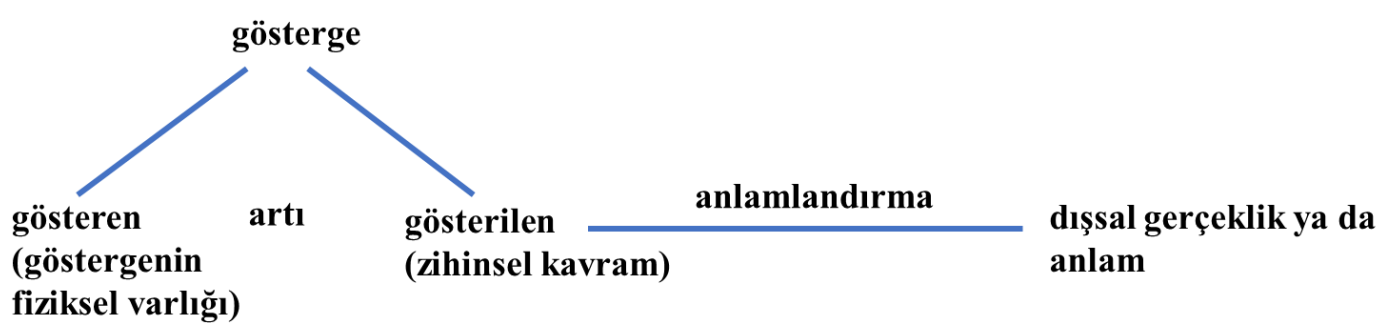

Kaynak: Fiske, 2003:66.

Sassure'un dizgesine göre göstergelerin anlamlandırılmasında anlamı en iyi belirleyen şey, bir göstergenin dişsal gerçeklikle ilişkisinden çok, o göstergenin diğer göstergelerle ilişkisidir. Saussure, göstergenin sistemdeki diğer göstergelerle ilişkisine değer adını verir. Saussure'a göre anlamı belirleyen aslında değerdir (Fiske, 2003:69).

Markaların logolarından tutun, seçtikleri renkler, reklam yüzleri, reklamlarında veya halkla ilişkiler çalışmalarında yaratmaya çalıştıkları algı ve stil ile ürünlerinin dizaynına kadar çok geniş bir yelpaze, göstergebilimin çalışmaları kapsamında incelenebilecek unsurlar barındırmaktadır. $\mathrm{Bu}$ nedenle, bir markanın itibarını oluşturan imaj toplamının tüm bileşenlerinin dayandığı algılar toplamını sembolize eden unsurlar göstergebilimsel anlamda çeşitli göndermelerle tüketicilerin zihinlerinde ve algılarında izler bırakmakta, dolayısıyla da satın alınmasını sağlamaktadır.

\section{Marka İletişimi ve Unsurları}

Günümüzde kurumların sahip olduğu en değerli varlıkların başında maddi olduğu kadar manevi değerler de gelmektedir. Söz konusu manevi değerlerin başında gelen marka, düz bir ürüne özel anlamlar yüklemek olarak tanımlanmaktayken, günümüzde tüketicilerin yaşamlarının her yönüne nüfuz eden bir kavram olarak karşımıza çıkmaktadır. Markaların varlığı, tüketicilerin ekonomik, sosyal, kültürel, sportif ve dini yaşamlarında hissedilmektedir.

Aaker'e göre (2010) marka iletişimi, hedef kitlenin bir marka hakkında sahip olduğu algılarındaki boşluğu kapatmayı amaçlayan kurumların tüm iletişim çabalarını kapsamaktadır Marka iletişimi, bir 
kurumun ya da bir markanın ürünlerinin tüketicileri etkilemeye çalışan ve tüketici tutumlarına yönelik pazarlama çalışmalarının tümünü kapsamaktadır. Etkili marka iletişimi, kurum ve kurumun ürünleri için başarılı pazarlama ve yapı değerleri için gerekli bir ön şart olarak görülmektedir. Markanın değerini oluşturabilmek için en etkili yol medyayı en etkili biçimde kullanmaktır.

$\mathrm{Bu}$ süreçte hedef kitleye doğru mesajlar aktarmak ve gerekli yanıtı ortaya çıkarmak için net bir biçimde iletişim kurmak esastır. Lim'in (2010) de belirttiği gibi, her iletişim biçiminde gerekli olduğu gibi marka iletişimi de açık, tutarlı ve sabit olmalıdır. Bir marka mesajı, bir markanın ne olduğu ve ne olmadığı konusunda açık ve net olmalıdır. Marka iletişiminin içeriği geliştirilerek daha sonra her iletişim aracı için uyarlanmaktadır. Ayrıca, marka iletişiminde hedef kitleye yönelik aynı marka mesajını yinelemek gerekmektedir. Marka iletişimi, marka değer yönetimi ile bağlantılı bir faaliyettir. Bu nedenle pazarlama iletişimi, marka iletişiminin temelini oluşturmaktadır. Marka iletişimi, bir kurumun en yüksek kademesini içermektedir, çünkü söz konusu kavram strateji oluşturma ve uygulama, önemli finansal katılım ve sağlam bir pazarlama programı ile ilgilidir. Marka yönetimi ve marka değeri optimizasyonu için kuruluşun tüm üyelerinin taahhüdü ve çabası gereklidir. Bu nedenle, yöneticinin asıl görevi, finansal ve pazarlama yönetimini birleştirmek için bir dayanak noktası işlevi görmektedir ve sonuçta entegre bir marka iletişimi çabasını önleyebilecek iç engelleri ortadan kaldırmaktır. Marka iletişimi, kurumların değer tekliflerini nasıl, ne zaman ve kime iletmeyi planladığını içeren genel marka stratejisinin bir parçasıdır. Markalaşma, tutarlı bir iletişim, ortak bir görünüm ve his elde etme, tek bir sesle konuşma ile bağlantılı olmaktadır.

Denilebilir ki, marka iletişimi, şirketin markasını yönetmek için tüm iletişimi entegre eden bütünsel bir iletişim stratejisidir. Aynı zamanda marka iletişimi mesajını açık ve net olarak ifade eden, hedef kitleyi duygusal olarak etkileyen ya da etkileyecek çalışmalar yapan, hedef kitleye güven veren tüm unsurları içermektedir.

Marka iletişimi kurumun hedeflere ulaşması gerektiği noktalarda vaatlerini belirli kılan bir iletişim yönetimidir. Marka ve marka iletişimi, kurum ve kurumun değer teklifleri için pazarlamadaki başarıyı belirlemede esastır.

Büyük markaların geliştirilmesi ve yönetilmesi; derinlemesine analizler, yaratıcılık ve uzman analizi gerektiren bir süreç olarak görülmektedir. Ayrıca, belirli bir hedef kitleye yönelik odaklanılmış iletişim stratejisi esastır. Bu stratejilerinden birisi sadık müşteriler elde etmektir. Her marka kendini benzersiz ve biricik olarak konumlandırarak müşterilerine kendilerini özel hissettirmekte ve kendisine sadakat duymasını sağlamaktadır. Marka-müşteri ilişkisi bu bakımdan iki insan arasındaki sadık bir ilişkiye de benzetilebilir.

Bir marka pazara çıktığında, ilk hedefi tüketicilerin dikkatini çekmektir. "Marka bilinirliği” ismi verilen bu süreçte tüketicilerin marka hakkında bilgisi sınırlıdır. Tüketicilerin markaya karşı farkındalığı ne kadar artarsa benzer biçimde tüketiciler tarafından bilinen marka niteliği de o kadar artmaktadır. Bu nedenle tüketiciler sadece markayı tanımakla kalmaz aynı zamanda marka ve ürün hakkında daha fazla bilgi sahibi olurlar. Bu aşamaya da marka bilgisi denir.

Zaman geçtikçe ve daha yoğun bir biçimde iletişim kurdukça, tüketicilerin zihninde (marka imajı olarak adlandırılır) marka hakkında belirli bir imaj oluşturmak için ilişkilendirilecek belirli bir algı söz konusu olmaktadır. Tüketiciler ürünlerle veya markayla doğrudan temas kurmakta, böylece tüketiciler markayla ilgili yeni anlamlar ve duygular oluşturan, markanın imajını güçlendiren marka ile ilgili özel deneyime sahip olmaktadır. Bu aşamaya marka deneyimi denir. İyi bir anlam ve özel bir his veren, olumlu bir imaj ve heyecan verici deneyimlerin birleşimi, markanın tüketicilerin zihinlerindeki ve kalplerindeki konumunu güçlendirmekte, böylece marka tüketiciler tarafından daha fazla tercih edilmektedir. Tercih edilen bir marka, tüketicinin sadakatini kazanmakta, böylece tüketici başka bir markaya kolay kolay ilgi duymamaktadır. Bu aşamaya ise marka sadakati adı verilmektedir. 
Sonuç olarak tüketiciler bir markaya sadece sadık değil aynı zamanda aidiyet göstermekte, marka tüketicilerin yaşam değerlerinin bir parçası haline gelmekte, yaşam üzerindeki bakış açılarını etkileme konusunda güçlü bir anlayışa sahip olmaktadır.

Denilebilir ki, bir marka hazların ve arzuların cevabı haline geldiği veya tüketicinin yaşam değerlerinin ve kültürünün, yani marka maneviyatının bir parçası haline geldiği noktada, tüketicilerin kalplerinde yer alan bir markanın yüksek başarısından bahsedilebilmektedir. Buna bağlı olarak, marka sadakatinden marka imajına kadar olan süreçte zihin kazanma aşaması önemli görülmekte, marka deneyiminin ise pazar payı kazanma aşamasında oldukça önemli olduğu bilinmektedir. Bu noktadan hareketle marka sadakati, duygusal paylaşım aşaması ve marka maneviyatı ise sosyal paylaşım elde etmek üzerine kurgulanmaktadır.

Günümüz marka iletişim çalışmaları çok geniş bir alanda farklı pek çok uygulamayla karşımıza gelse de özellikle iki binli yıllar sonrasında artan dijital pazarlama ve dijital medya kullanımı doğrultusunda markalar iletişim çalışmalarını dijital ortamlara kaydırmışlardır. Hem ekonomik olması hem de "çoktan çoğa" iletişimin yaygınlaştığı sosyal medya uygulama ve paylaşımlarının artması dijital ortamlarda marka iletişimini hızlandırmıştır. Teknolojik olanakların artması bu hızı tüketiciler açısından daha teşvik edici hale getirmekte ve sürecin hız kazanması da marka iletişimine başarı kazandırmaktadır. Dolayısıyla teknolojik gelişmelerin artışı ile marka iletişiminin etkinliği karşılıklı olarak birbirlerini doğru orantılı şekilde etkilemektedir.

Geleneksel marka iletişimini sağlayan pazarlama iletişimi unsurları (reklam, halkla ilişkiler, kişisel satış, satış teşvik promosyou) çabalarının dijitale geçmesi, yukarıda açıklanan itibar ve marka algısının da dijital iletişim araçlarıyla ancak geleneksel metotların uygulanmasıyla gerçekleşmekledir. Diğer bir deyişle, dijital ortamda geleneksel metotlarla marka iletişimi sağlanırken, bu içeriklerin yaygınlaşması ve etki alanının gelişmesi dijital ortamlarla gerçekleşmektedir. Dolaysıyla dijital ortamda gerçekleşen bir iletişim çalışmasının tasarlanmasında, incelenmesinde ve değerlendirilmesinde genel kabul gören marka algısına dair strateji ve kuramlar da geçerliliğini korumaktadır.

Marka iletişimini sağlayan iletişim çalışmalarında dijital veya geleneksel uygulamalar olsun fark etmeksizin lüks tüketim markaları da iletişim stratejilerini gelişen şartlara uyum yönünde değiştirmişlerdir.

Lüks tüketim ürünleri de dijital iletişim çalışmaları yaparak genel hedef kitlelere hitap etmekte imaj transferlerinde ve markalarına olan istek, arzu, haz uyandıran motivasyonların gelişmesine çalışmaktadır. Lüks markalar daha dar ve spesifik bir tüketici hedef kitlesine sahip olmalarına rağmen genel hedef kitlelere yönelik bu çalışmalarında doğrudan ya da dolaylı olarak markaya yönelik istekleri uyandırırken kendilerinden bahsedilmesini sağlamakta ve potansiyel hedef kitlelerinin oluşması için tohumlama yapmayı gözetmektedirler diyebiliriz.

\section{Dijitalde Marka İmaj Transferi ve İtibar Göstergelerinin Rolex -Roger Federer Reklamları Üzerinden Göstergebilimsel İncelenmesi}

Rolex markasının Roger Federer’i kullandığı reklam görselleri üzerinden çeşitli açılardan incelemeler yapılan bu çalışmada genel bilgilendirme amaçlı olarak Rolex markası ile Roger Federer hakkında bilgi vermek yerinde olacaktır.

Rolex markası, 1905 yılında zamanının genç girişimcisi olan Hans Wilsdorf tarafindan kurulmuş, Londra merkezli olarak hayatına başlamasına rağmen daha sonra merkezini 1920'de Cenevre'ye taşımıştır. Duvar saatlerinin bilekte taşınmasına yönelik yaratıcı düşünceyi hayata geçiren Wilsdorf, 1926'da "Oyster" adı verilen ilk su geçirmez saatin yapımını gerçekleştirmiştir. Kısa süre sonra da Rolex 1927'de markanın saatlerinin su geçirmezliğini kanitlayan İngiliz yüzücü Mercedes Gleitze ile "Temsilcilik" konseptini başlatmıştır. O zamandan beri Rolex, çok sayıdaki istisnai partnerle bir araya gelmiş ve hem büyük organizasyonların girişimlerini hem de temsilcilerinin kişisel projelerini desteklemiştir (www.rolex.com/tr, 20.07.2020). 1931 yılında Rolex, Perpetual adını verdiği bir motor ile dünyanın ilk 
otomatik kurmalı mekanizmasını icat ederek, patentini almıştır. 1950'li yıllar itibarıyla büyük atılımlara geçen marka, Everest tepesindeki kullanımlarından derin su altı dalışlarına kadar pek çok yeryüzü alanında üstün performans sergileyen ve yıldan yıla kendini ve saat mekanizması ile materyallerini güncelleyerek geliştiren bir yükseliş yakalamıștır. Bugün Rolex her gün 2.000'den fazla saat üreterek, yıllık 4.5 milyar dolarlık bir satış rakamına sahiptir (www.paratic.com, 20.07.2020).

İsviçreli tenis sporcusu olan Roger Federer, tenis şampiyonluğunda Birinci sırada daha önce art arda 237 hafta ve toplamda 302 hafta kalarak bir rekor kırmıştır. Federer, emekli ve aktif tenis oyuncuları, önemli tenis çevreleri tarafından gelmiş geçmiş en iyi tenis oyuncusu olarak görülmektedir. Federer'in 19 Grand Slam şampiyonluğu bulunmaktadır ve erkekler tenis tarihinde bu seviyeye ulaşan ilk tenis oyuncusudur. Tarihte "Kariyer Grand Slam" yapan sekiz oyuncudan biridir. Ocak 2010 itibariyla art arda 23 Grand Slam yarı finali oynayarak kendisinden önceki rekoru yaklaşık olarak ikiye katlamıştır (www.haberler.com, 21.07.2020). Roger Federer, Rolex markası ile sponsorluk yaparak markanın yüzü olmuştur ve 2015 yılında yaklaşık 70 milyon dolarlık sponsorluk geliri elde eden en önemli tenis raketçisi olma unvanını da kazanmıştır (www.milliyet.com.tr, 21.07.2020).

\section{Roland Barthes'ın Düzanlam-Yananlam Göstergebilimsel Çözümleme Yöntemi}

Markalar, reklamlarında kullandıkları marka yüzü, objeler, logolar, renkler, afişs ve reklam tasarımları, müzik, cıngıl, yaratıcı düşünce, senaryo gibi pek çok öğeleriyle tüketicilerin kalplerinden ve gönüllerinden yer edinme çabası içerisindedirler. Bu çabalarını gerçekleştirirken en çok kullanılan yöntem "kişiselleştirme" yöntemi de denen tanınmış popüler bir kişi ya da kamuoyu önderi olan markanın tüm mesajlarıyla ortak noktalarda bulunan ve kişi ile marka imajı arasında duygusal değerlerde ortaklık bulunan figürleri kullanmaktır. Hatta öyle markalar vardır ki bu markalar ile marka yüzleri olan kişiler eşit şekilde algılanmaktadırlar. Böylece reklam yüzü veya tanıtım yüzü olan kişinin imajı ile marka imajını eşitlemekte ya da pekiştirmektedirler.

Markaların reklamlarını incelerken Roland Barthes'ın Göstergebilim inceleme yöntemini kullanarak, yapılan reklamların içerisinde barındırdığı göndermeleri analiz etmek geçerli bir yöntem olacaktır. Çünkü, Göstergebilim'in en önemli temsilcilerinden biri olan Roland Barthes göstergebilim alanındaki incelemelerini yalnızca dilbilimsel olarak ele almaz. Barthes, pek çok olgu, moda, sanat, dilbilim, resim gibi farklı disiplinlerin de göstergebilimsel çözümlemelerini gerçekleştirmiştir. Roland Barthes'in göstergebilim disiplinini 4 özelliği vardır: 1. Dil ve Söz, 2. Gösteren ve Gösterilen, 3. Dizge ve Dizim ve 4. Düzanlam ve Yananlamdır (Bircan, 2015:1999).

Barthes'a göre düzanlam, göstergenin neyi temsil ettiğini, yan anlam ise göstergenin nasıl temsil edildiğini konu edinir. Barthes’a göre bir gösterge "Saussure’ün söylediği gibi temelde

bir düzanlam biçimidir. Yani gösteren dolayımsız bir biçimde özel bir nesneyi adlandırır ya da neye gönderme yaptığını açıkça belirtir. Bunun yanı sıra, göstergeler kültürel olarak belirlenmiş anlamlara ya da ayrıca anlamları olan yananlamlara gönderme yapar, bir gösterge kendi kendine başka göstergenin, bir yananlamın ya da konum gibi kültürel bir değeri gösteren ikincil dereceli bir göstergenin göstereni olabilir (Bircan, 2015:20).

Barthes dilbilimsel çözümlemeden göstergebilimsel çözümlemeye geçerken düzanlam (denotation), yananlam (connotation), üstdil (metalanguage) gibi gösterge düzlemlerinden yararlanmıştır. Bu üç anlamlama dizgesi de bir anlatım (gösteren) ve bir içerik (gösterilen) dizgesine sahiptir. Gösteren, gösterilen ve göstergeden oluşan ilk dizge bize düzanlamı verir. Düzanlam, anlamlandırma düzeyinde ilk sırada yer alır ve görünür haliyle anlama göndermede bulunur. Yananlam düzlemi ilk dizgenin göstergesini kendi dizgesinin göstereni haline getirir. Barthes'a göre "birinci dizge düzanlam; birinci dizgeyi kapsayan ikinci dizgeyse yananlam düzlemini oluşturur. Dolayısıla, "bir yananlam dizgesi, anlatım düzleminin de bir anlamlama dizgesince oluşturulduğu dizgedir" (Barthes, 1979:88). Düzanlam düzlemi anlamlandırmada son derece açık olan birincil anlamlara gönderme yapar. Yananlam düzleminde ise insanın içinde yetişmiş olduğu kültürel ve toplumsal yönü ön plana geçtiği için bu düzlem mit ve çağrışım boyutlarını içerir (Bircan, 2015:25). 
Şekil 3: R. Barthes'in Anlamlandırma Şeması

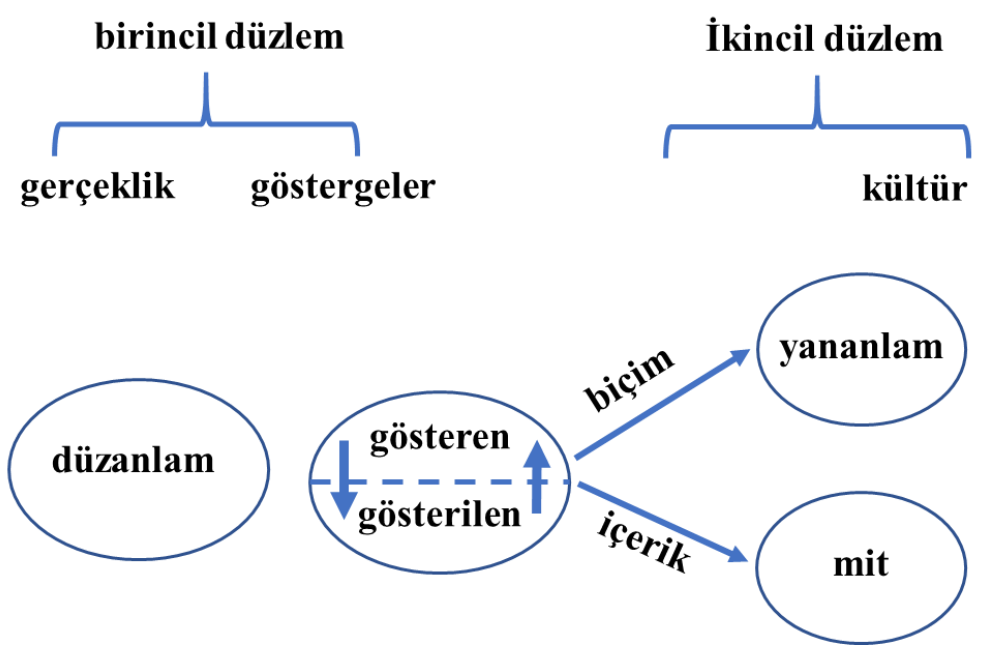

Kaynak: Fiske, 2003, 120.

Barthes, dinamik bir yapıya sahip olan mitlerin kültürün gereksinimlerine ve değerlerine uyum sağlayabilmek için çok çabuk değiştiklerini söyler. Yananlam ve mit göstergelerin anlamlandırılma sürecinde ikinci düzlemdeki ele alınışının etkili yollarıdır. Barthes, bu noktada anlamlandırmanın başka bir boyutundan bahseder. Bu da simgesel anlamlandırmadır. "Bir nesne, uzlaşım ve kullanım aracılığıyla başka bir şeyin yerine geçmesini mümkün kılan bir anlam kazandığında simge haline gelir (Bircan, 2015:27). Markaların reklamlarında kullanılan unsurların düzanlam ve yananlam olarak çözümlenmesi, tüketicilerine görsel olarak sunduklarının benliklerinde yarattı̆gı izlenimleri çözümlemek açısından önem taşımaktadır.

Böylece markalar, kullandıkları reklam unsurlarıyla tüketicilerinde "imaj" yaratmakta sonrasında da bu imaj bir şekilde "itibar ve bir "talep" olarak tekrara markaya dönmektedir.

Bu çalışmada Rolex markasının marka yüzü olan Roger Federere’e ait dijital ortamda kullanılan dört ayrı afiş, Roland Bhartes'in düzanlam ve yananlam çözümlemesi kullanılarak analiz edilmiştir. Ayrıca genel bir tüketici kitlesine Rolex markası ile Roger Federer hakkında soruların yöneltildiği bir alan araştırması gerçekleştirilmiştir. Her iki araştırma ve inceleme ile Rolex markasının Roger Federer'in kullanıldığ 1 reklam afişleriyle tüketicilerde yaratmaya çalıştığı etki değerlendirilerek, sonuçlara varılmaya çalış1miştır. 


\section{Rolex-Federer Dijital Reklam Görseli 1 Göstergebilimsel Çözümlemesi}

Resim 1: Rolex-Roger Federer Dijital Reklam Görseli 1

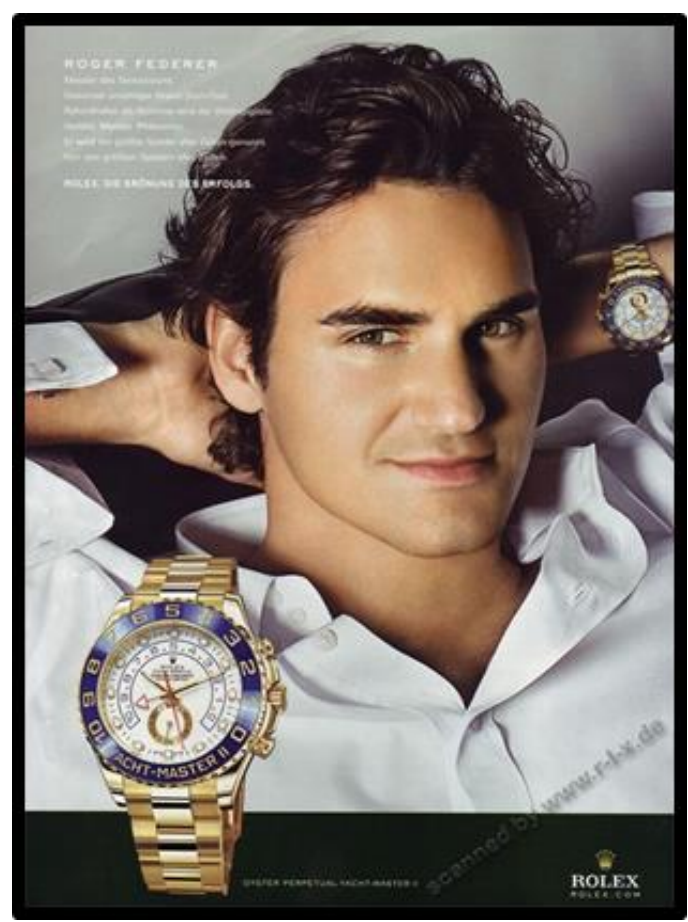

Kaynak: http://chronoscope.ru

Yukarıda yer alan Rolex-Roger Federer Dijital Reklam Görseli 1 Rolex markasının dijital reklam tasarımı, aşağıdaki tabloda düzanlam ve yananlam olarak değerlendirilmiştir.

\begin{tabular}{|c|c|c|c|c|}
\hline \multicolumn{5}{|c|}{ Rolex- Roger Federer Dijital Reklam Görseli 1 Göstergebilimsel Çözümleme Tablosu } \\
\hline GÖSTERGE & $\begin{array}{l}\text { DÜZANLAM } \\
\text { GÖSTEREN }\end{array}$ & DÜZANLAM GÖSTERILEN & YANANLAM GÖSTEREN & YANANLAM GÖSTERILLEN \\
\hline Kișí & $\begin{array}{l}\text { ROGER } \\
\text { FEDERER }\end{array}$ & $\begin{array}{l}\text { Dünyaca tanımmıs, şampiyonlukları olan } \\
\text { tenis sporcusu. Rolex Markası reklam } \\
\text { yüzz̈. }\end{array}$ & $\begin{array}{l}\text { Roger Federer'in gülümseyen, temiz traş } \\
\text { olmuş bir cilt ile beyaz renkte bir gömlek } \\
\text { ve kolunda Rolex markalı saati ile } \\
\text { okuyucuları gözlerinin içerisine } \\
\text { odaklanmıs bakışlarılyla ellerini başmın } \\
\text { arkasnda birleştirdiği rahat bir duruşa } \\
\text { sahip görseli... }\end{array}$ & $\begin{array}{l}\text { Roger Federer'in, başarrya odakl, sporcu kimliğ ile Rolex markasmın bütünleşmesi } \\
\text { yansittlmaktadrr. Roger Federer'in kendinden emin ve gururlu, başarlarmı, dünyaca } \\
\text { sevilen ve beğenilen birisi olduğunun, yakışıkl, çekici, genç, dinamik, enerjik sporcu } \\
\text { kimliği ile bütünleşen, kendinden emin bir şekilde ve hatta biraz çapkm ve kendini } \\
\text { beğenen şekilde rahat duruşu, Rolex markasmın da benzer niteliklerde özelliklerle } \\
\text { anlassilmasma yönelik etkiler barndırmakta ve bu etkiler Federer'in görüntüsü ile } \\
\text { bilikte yansittlmaktadrr. }\end{array}$ \\
\hline SAAT & $\begin{array}{l}\text { ROLEX KOL } \\
\text { SAATI }\end{array}$ & $\begin{array}{l}\text { İsviçre kökenli, lüks saat segmentinde } \\
\text { olan Rolex markalı kol saati. }\end{array}$ & $\begin{array}{l}\text { Sarı altın renginde, büyük ve içerisinde } \\
\text { birçok zaman göstergesi mekanizması } \\
\text { olan, şı, zengin ve havalı duran erkek } \\
\text { kol saati. }\end{array}$ & 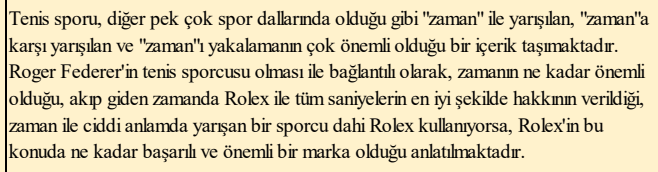 \\
\hline GÖMLEK & $\begin{array}{l}\text { BEYAZ RENK } \\
\text { GÖMLEK }\end{array}$ & $\begin{array}{l}\text { Beyaz renk safllk, temizlik, asalet, } \\
\text { seçkinlik ve klas etkisi ile birlikte beyaz } \\
\text { renk gömleğin iş ve gündelik hayatta en } \\
\text { çok tercih edilen bir erkek giyim unsuru } \\
\text { olması. }\end{array}$ & $\begin{array}{l}\text { Krrışksız, çok iyi ütülenmiş, kaliteli bir } \\
\text { kumaş yapısma sahip, kol düğmeleri ile } \\
\text { kullanılan, klas, şk ve asil duran beyaz } \\
\text { renkli gömlek. Beyaz gömlek, } \\
\text { dünyadaki iss insanlarnm ve eski zaman } \\
\text { asil kişilerinin sıklkla tercih ettiği, } \\
\text { zenginlik ve asaleti temsil eder şekilde } \\
\text { gösterilen gömlek. Beyaz gömlek, } \\
\text { gündelik yaşantıda kullanılmasmın yanı }\end{array}$ & 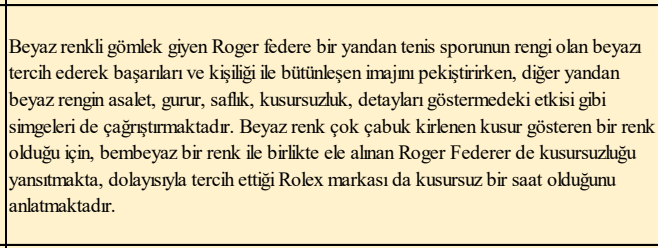 \\
\hline YEŞIL & RENK & $\begin{array}{l}\text { Rolex markası kurumsal renklerinden } \\
\text { birisi. (Diğer renk altın sarısı.) }\end{array}$ & \begin{tabular}{|l|} 
Rolex markasmın kurumsal rengi olan \\
yeşil renk, kalı bir bant şeklinde zemin \\
rengi olarak reklam görselinin alt kısmma \\
yerleștirimiștir. Bu yeşil renk zemine \\
aynca Rolex marka saat görseli \\
yerleștirilmiştir.
\end{tabular} & $\begin{array}{l}\text { Renk dilinde yeşil renk, refah, doğallk, doğa, zenginlik, pozitif duygular, bereket ve } \\
\text { finans dünyasmı temsil etmektedir. Rolex markasınm kurumsal renk olarak yeşil rengi } \\
\text { seçmesi de simgesel olarak, Rolex markası seçildiği takdirde marka ile özdeşleşen söz } \\
\text { konusu çağrışsmlarm kazanilacağı mesajmı vermektedir. }\end{array}$ \\
\hline
\end{tabular}




\section{Rolex- Roger Federer Dijital Reklam Görseli 2 Göstergebilimsel Çözümlemesi}

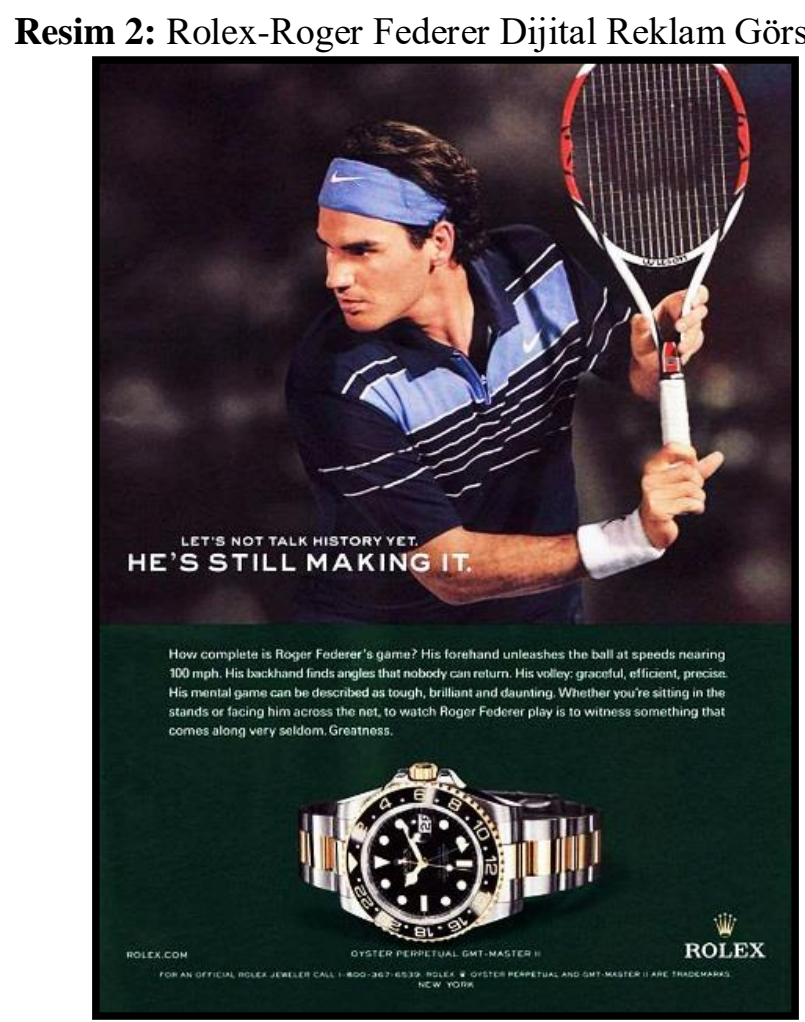

Kaynak: https://www.ebay.ca

Yukarıda yer alan Rolex-Roger Federer Dijital Reklam Görseli 2 Rolex markasının dijital reklam tasarımı, aşağıdaki tabloda düzanlam ve yananlam olarak değerlendirilmiştir. 


\begin{tabular}{|c|c|c|c|c|}
\hline \multicolumn{5}{|c|}{ Rolex- Roger Federer Dijital Reklam Görseli 2 Göstergebilimsel Çözümleme Tablosu } \\
\hline GÖSTERGE & \begin{tabular}{|l} 
DÜZANLAM \\
GÖSTEREN
\end{tabular} & DÜZANLAM GÖSTERILEN & YANANLAM GÖSTEREN & YANANLAM GÖSTERILEN \\
\hline Kiși & $\begin{array}{l}\text { ROGER } \\
\text { FEDERER }\end{array}$ & $\begin{array}{l}\text { Dünyaca tanımııs, şampiyonlukları olan } \\
\text { tenis sporcusu. Rolex Markası reklam } \\
\text { yüzzi. }\end{array}$ & $\begin{array}{l}\text { Tenis raketini topa vurmak üzere } \\
\text { harekete geçmiş, gözleri muhtemelen } \\
\text { tenis topuna odaklanmış, bir başka spor } \\
\text { markası olan Nike markasmm logosunu } \\
\text { taşıan t-shirt ve saç bandı takmış olan } \\
\text { Roger Federer. }\end{array}$ & 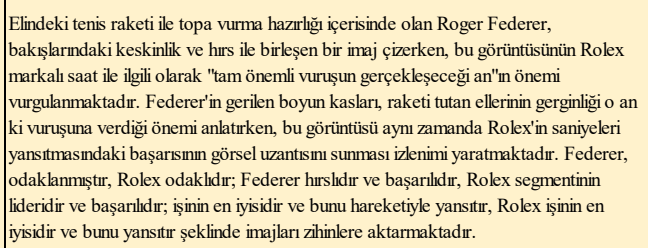 \\
\hline RAKET & TENIS RAKETI & \begin{tabular}{|l|} 
Tenis oynamak üzere, doğal hayvan \\
bağırsağndan yapulan ve "kordaj" \\
denilen fileli kısmmnn seçiminin tenisteki \\
başarıyı doğrudan etkilediği için özel \\
olarak seçilmesi gereken spor aleti.
\end{tabular} & $\begin{array}{l}\text { Roger Federer'in tenis raketindeki } \\
\text { "kordaj" kssmnndaki her bir file karesinin } \\
\text { eşit araliklarla ve muntazam şekilde yer } \\
\text { alması, raket üzerindeki renk ve } \\
\text { desenlerin simetrik ve belli bir harmoni } \\
\text { içerisinde olması, Roger Federer'in } \\
\text { raketi profesyonel ve özel bir tarzda } \\
\text { tutmus olması. }\end{array}$ & 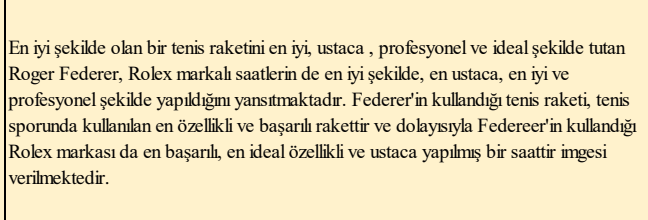 \\
\hline SAAT & ROLEX SAAT & $\begin{array}{l}\text { İsviçre kökenli, lüks saat segmentinde } \\
\text { olan Rolex markalı kol saati. }\end{array}$ & $\begin{array}{l}\text { Gümüss metal renk üzerinde altın } \\
\text { renginde şerit olan çelik kordonlu, siyah } \\
\text { kadranlı Rolex markalı erkek kol saati. }\end{array}$ & 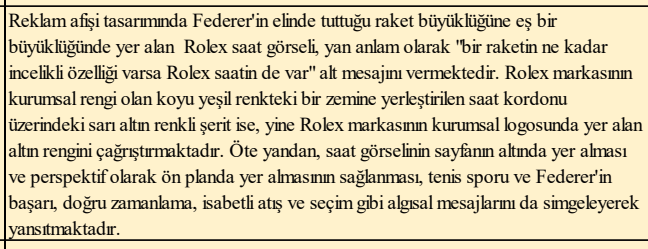 \\
\hline $\begin{array}{l}\text { MARKA } \\
\text { SEMBOLÜ }\end{array}$ & $\begin{array}{l}\text { NIKE MARKASI } \\
\text { LOGOSU }\end{array}$ & $\begin{array}{l}\text { Küresel spor ürünleri markası olan Nike } \\
\text { markasminn beyaz renk logosu. Nike, } \\
\text { Roger fed Erer'in tenis sporundaki resmi } \\
\text { sponsorudur ve Federer Nike markası } \\
\text { kullanarak müsabakalara çikmaktadır. } \\
\text { (Nike aynı zamanda Federer için RF } \\
\text { admda bir alt marka oluşturmuștur ve } \\
21 \text { yildr Federer'in sponsorluğunu } \\
\text { yapmaktadr. } 2018 \text { yllnda bu } \\
\text { sponsorluk bitmiştir ancak RF markası } \\
\text { Nike tarafindan halen kullanilmakta } \\
\text { Federer de nikel markalı ayakkabıları } \\
\text { halen giymektedir.) }\end{array}$ & $\begin{array}{l}\text { Küresel spor ürünleri markası Nike ile } \\
\text { dünyaca ünlü sporcu Federer işbirliği ve } \\
\text { sponsorluğu }\end{array}$ & $\begin{array}{l}\text { Nike markası ile Rolex markasmın birleşiminde imaj olarak her ikisinin de elit ve lüks } \\
\text { segmentte yer alan ürünlerinde sektör lideri olmaları, başarll, dünyaca tanımış pek } \\
\text { çok sporcunun tercih ettiği markalar olmaları ve sağlamlk, kalite, güçlü marka gibi } \\
\text { simgeleri marka görselleri ve isimlerinde toplamış olmaları mesajları yer almaktadr. } \\
\text { Federer- Nike-Rolex üçlü markasmmn bir araya gelişi, başarı, kalite ve liderliğin bir } \\
\text { araya gelişini sembolize etmektedir. }\end{array}$ \\
\hline YEŞSiL & RENK & $\begin{array}{l}\text { Rolex markası kurumsal renklerinden } \\
\text { birisi. (Diğer renk altın sarıs.) }\end{array}$ & \begin{tabular}{|l|} 
Rolex markasmmn kurumsal rengi olan \\
yeşil renk, kalı bir bant şeklinde zemin \\
rengi olarak reklam görselinin alt kısmmna \\
yerleştirilmiştir. Bu yeşil renk zemine \\
ayrica Rolex marka saat görseli \\
yerleștirilmiştir.
\end{tabular} & $\begin{array}{l}\text { Renk dilinde yeşil renk, refah, doğalllk, doğa, zenginlik, pozitif duygular, bereket ve } \\
\text { finans dünyasmı temsil etmektedir. Rolex markasmın kurumsal renk olarak yeşil rengi } \\
\text { seçmesi de simgesel olarak, Rolex markası seçildiği takdirde marka ile özdeşleşen söz } \\
\text { konusu çağrıșmmların kazanlacağı mesajmı vermektedir. }\end{array}$ \\
\hline
\end{tabular}

\section{Rolex-Roger Federer Dijital Reklam Görseli 3 Göstergebilimsel Çözümlemesi}

Resim 3: Rolex-Roger Federer Dijital Reklam Görseli 3

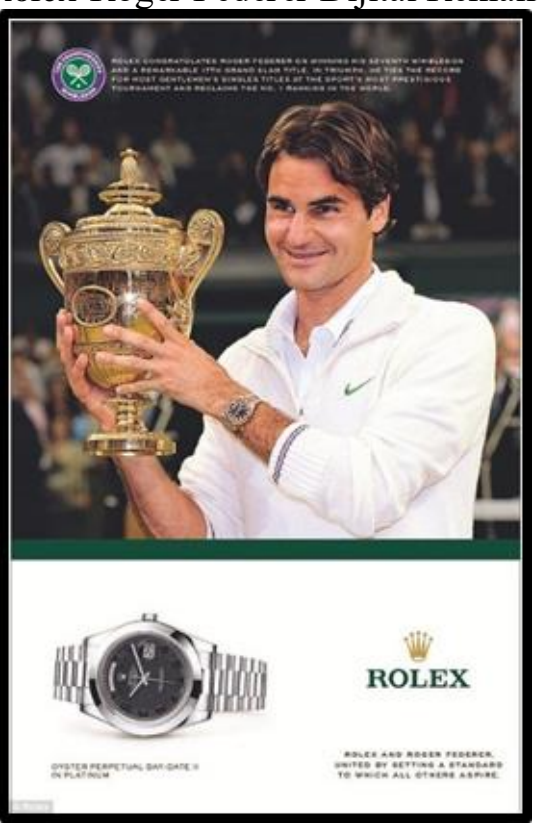

Kaynak: https://cofounderstown.com 
Yukarıda yer alan Rolex-Roger Federer Dijital Reklam Görseli 3 Rolex markasının dijital reklam tasarımı, aşağıdaki tabloda düzanlam ve yananlam olarak değerlendirilmişstir.

\begin{tabular}{|c|c|c|c|c|}
\hline \multicolumn{5}{|c|}{ Rolex-Roger Federer Dijital Reklam Görseli 3 Göstergebilimsel Çözümleme Tablosu } \\
\hline GÖSTERGE & $\begin{array}{l}\text { DÜZANLAM } \\
\text { GÖSTEREN }\end{array}$ & DÜZANLAM GÖSTERILLEN & YANANLAM GÖSTEREN & YANANLAM GÖSTERILEN \\
\hline Kiși & $\begin{array}{l}\text { ROGER } \\
\text { FEDERER }\end{array}$ & $\begin{array}{l}\text { Dünyaca tanınmıs, şampiyonlukları olan } \\
\text { tenis sporcusu. Rolex Markası reklam } \\
\text { yüzü. }\end{array}$ & \begin{tabular}{|l|} 
Golden Grand Slam kupasm ellerinde \\
tutan Dünyaca ünlü sporcu Roger \\
Federer. Federer, beyaz spor \\
kiyafetleriyle gülümseyerek objektiflere \\
poz vermektedir.
\end{tabular} & $\begin{array}{l}\text { Roger Federer, tek erkeklerde en çok Grand Slam kupası kazanan sporcudur. Bu } \\
\text { bağlamda, "Rolex markası da tüm saat markası sralamalarnda ve kendi } \\
\text { kategorisindeki yarşşalarda en çok kupa kazanan saat olmaktadır" mesajı } \\
\text { verilmektedir. }\end{array}$ \\
\hline KUPA & $\begin{array}{l}\text { GRAND SLAM } \\
\text { KUPASI }\end{array}$ & \begin{tabular}{|l|} 
Grand Slam, Uluslararası Tenis \\
Federasyonu tarafindan dört büyük \\
tenis turnuvasmdan her birine verilen \\
isimdir. Her sezon gerçekleşirler. Dört \\
kupayı kazanan sporcu Olimpiyatlarda \\
da kazanırsa Golden Grand Slam \\
kazanmıs olur.
\end{tabular} & $\begin{array}{l}\text { Altın renkli, parlak ve üzerinde işlemeler } \\
\text { olan, birçok spor müsabakası } \\
\text { kupalarndan büyük ve gösterişli duran } \\
\text { Grand Slam kupası. }\end{array}$ & 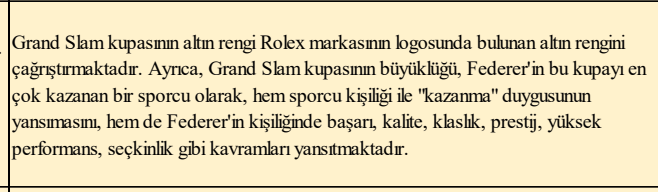 \\
\hline $\begin{array}{l}\text { POLO YAKALI } \\
\text { T-SHIRT }\end{array}$ & $\begin{array}{l}\text { BEYAZ RENKLI } \\
\text { POLO YAKALI } \\
\text { T-SHIRT }\end{array}$ & $\begin{array}{l}\text { Beyaz renkli polo yakali t-shirt giymiş } \\
\text { olan Roger Federer, Grand Slam } \\
\text { kupasmı iki eliyle tutarak kaldrmakta ve } \\
\text { yüzünde muttuluk gülümsemesiyle } \\
\text { kameralara poz vermektedir. }\end{array}$ & $\begin{array}{l}\text { Son yilları erkek giyim modasmda ön } \\
\text { plana çlkan "cool" ve "trend" bir olarak } \\
\text { görülen "casual" giyim tarzmm en önemli } \\
\text { unsurlarndan birisi olan polo yakal t- } \\
\text { shirt ve sweatshirt giymiş bulunan Roger } \\
\text { Federer, beyaz rengi tercih etmiştir. }\end{array}$ & $\begin{array}{l}\text { Beyaz renk bir yandan tenis sporunu simgelerken, diğer yandan renk dilinde safllk, } \\
\text { kalite, seçkinlik, dürüstlük, başarı gibi pozitif anlamlar içermektedir. Bütün bu } \\
\text { anlamlarla örülmüş mesajlar taşyan izleniminin yanı sra sportif bir moda tarzmı da } \\
\text { yansitan polo yakaht t-shirt ve sweatshirt giyim şekli de ayrıa spor ve sporcu } \\
\text { tanmlarmı destekleyen mesajlar taşmaktadr. Roger Federe gibi tenis sporunun en üst } \\
\text { mertebesinde yer alan bir kişinin Rolex markası kullanması da beyaz renk ve sportif } \\
\text { giyimin tüm olumlu mesajlarmı saat markasma transfer etmektedir. }\end{array}$ \\
\hline SAAT & ROLEX SAAT & $\begin{array}{l}\text { İsviçre kökenli, lüks saat segmentinde } \\
\text { olan Rolex markalı kol saati. }\end{array}$ & $\begin{array}{l}\text { Sarı altın renginde, büyük ve içerisinde } \\
\text { birçok zaman göstergesi mekanizması } \\
\text { olan, şı, zengin ve havalı duran erkek } \\
\text { kol saati. }\end{array}$ & 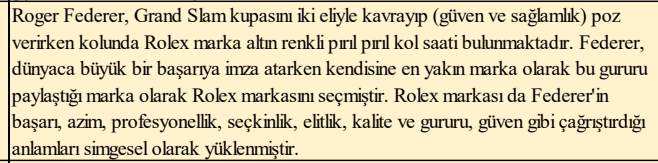 \\
\hline YEȘIL & RENK & $\begin{array}{l}\text { Rolex markası kurumsal renklerinden } \\
\text { birisi. (Diğer renk altm sarısı.) }\end{array}$ & \begin{tabular}{|l|} 
Rolex markasmin kurumsal rengi olan \\
yeşil renk, kalı bir bant şeklinde zemin \\
rengi olarak reklam görselinin alt kısmmna \\
yerlesțirilmiştir. Bu yeșil renk zemine \\
ayrca Rolex marka saat görseli \\
yerleştirilmiş̧tir.
\end{tabular} & $\begin{array}{l}\text { Renk dilinde yeşil renk, refah, doğallik, doğa, zenginlik, pozitif duygular, bereket ve } \\
\text { finans dünyasmı temsil etmektedir. Rolex markasmın kurumsal renk olarak yeşil rengi } \\
\text { seçmesi de simgesel olarak, Rolex markası seçildiği takdirde marka ile özdeşleșen söz } \\
\text { konusu çağrışmlarm kazanilacağı mesajmı vermektedir. }\end{array}$ \\
\hline
\end{tabular}

\section{Rolex-Roger Federer Dijital Reklam Görseli 4 Göstergebilimsel Çözümlemesi}

Resim 4: Rolex-Roger Federer Dijital Reklam Görseli 4

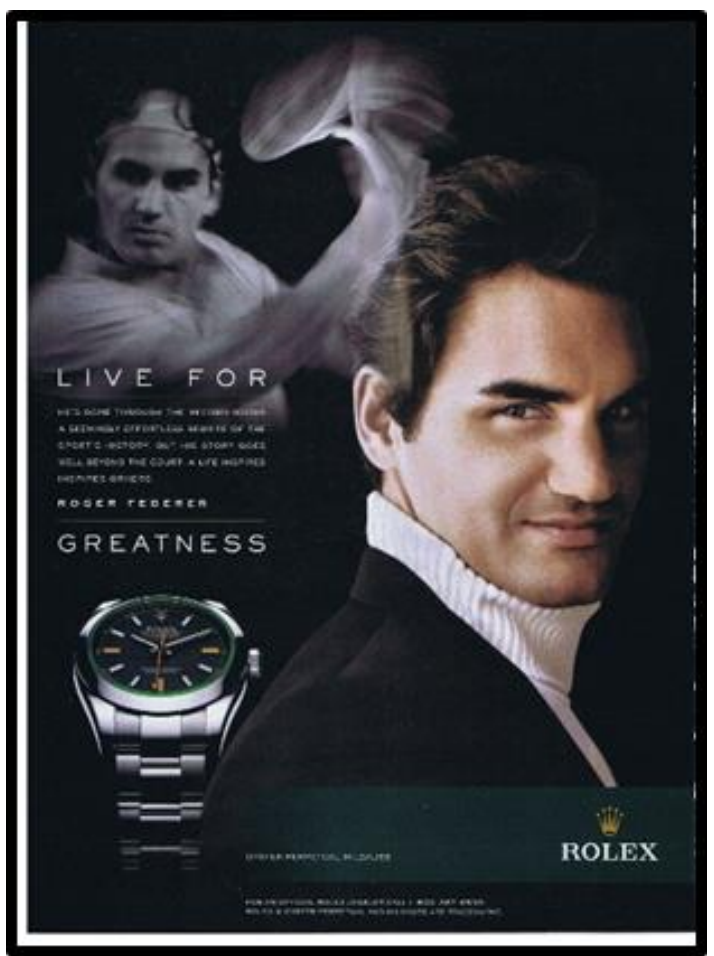

Kaynak: https://www.oversmartwatch.com

Yukarıda yer alan Rolex-Roger Federer Dijital Reklam Görseli 4 Rolex markasının dijital reklam tasarımı, aşağıdaki tabloda düzanlam ve yananlam olarak değerlendirilmiştir. 


\begin{tabular}{|c|c|c|c|c|}
\hline \multicolumn{5}{|c|}{ Rolex-Roger Federer Dijital Reklam Görseli 4 Göstergebilimsel Çözümleme Tablosu } \\
\hline GÖSTERGE & $\begin{array}{l}\text { DÜZANLAM } \\
\text { GÖSTEREN }\end{array}$ & DÜZANLAM GÖSTERILEN & YANANLAM GÖSTEREN & YANANLAM GÖSTERILEN \\
\hline Kiși & $\begin{array}{l}\text { ROGER } \\
\text { FEDERER }\end{array}$ & $\begin{array}{l}\text { Dünyaca tanımıs, şampiyonlukları olan } \\
\text { tenis sporcusu. Rolex Markası reklam } \\
\text { yüzzi. }\end{array}$ & \begin{tabular}{|l|} 
Bu görselde Roger Federer, gizemli bir \\
gülümsem ile koyu renkli bir ceket \\
içerisinde oldukça koyu bir zeminde \\
göze çarpan yüzï, gülümsemesi ve \\
beyaz dik yakahl kazağı ile \\
görünmektedir.
\end{tabular} & $\begin{array}{l}\text { Görselde, siyah rengin hakim olduğu genel renk algssmın verdiği çağrışm asalet, elittik } \\
\text { ve gizemli bir atmosferdir. Federer de yüzündeki gülümseme ile hem gurur hem de } \\
\text { gizem ifade etmektedir. Federer'in tenis sporu ile ilgili olduğu bu görseldeki çoğunluk } \\
\text { alanı kaplayan görüntüsünden net bir şekilde anlaşllmamakta, yan unsurlarla tenis } \\
\text { sporcusu gerçeği çağrşstrtrlmaktadr. }\end{array}$ \\
\hline SAAT & ROLEX SAAT & $\begin{array}{l}\text { İsviçre kökenli, lüks saat segmentinde } \\
\text { olan Rolex markah kol saati. }\end{array}$ & $\begin{array}{l}\text { Gri metal renkte çelik kordonlu, siyah } \\
\text { kadranlı Rolex marka erkek kol saati. } \\
\text { Saat görseli kadranı yukarida ve dik } \\
\text { duracak şekilde kullanlmıştr. }\end{array}$ & $\begin{array}{l}\text { Roger Federer de tppkı görseldeki Rolex saat gibi, dik ve gururlu durmaktadrr, üstelik } \\
\text { saatin kadranı gibi siyah renk ceket giymiş̧tir. Roger Federer ile Rolex saat birbirine eş } \\
\text { bir duruşu renk ve görsel algida sunulmaktadrr. Federer'in simgelediğ tüm başarı, } \\
\text { çekicilik, gizem, seçkinlik, prestij ve kalite böylece Rolex markalı saate transfer } \\
\text { olmaktadrr. }\end{array}$ \\
\hline $\begin{array}{l}\text { DiK YAKALI } \\
\text { KAZAK }\end{array}$ & $\begin{array}{l}\text { BEYAZ } \\
\text { RENKTE DIK } \\
\text { YAKALI } \\
\text { KAZAK }\end{array}$ & $\begin{array}{l}\text { Erkek giyim modasinda kimi zaman ön } \\
\text { plana çkan kimi zaman gerileyen bir } \\
\text { şekilde gündeme gelen dik yakalı kazak, } \\
\text { genç, dinamik, sportif ve farkl giyimi } \\
\text { benimseyen erkekler tarafindan tercih } \\
\text { edilmektedir. }\end{array}$ & $\begin{array}{l}\text { Beyaz renkte, siyah -muhtemelen blazer } \\
\text { ceket içerisine giyilen dik yakah kazak, } \\
1960 \text { 'l ylllardan günümüze kadar gelen } \\
\text { erkek modasmın bir unsurudur. } \\
\text { Çoğunlukla Franszz ve İngiliz aristokrat } \\
\text { smifindan erkeklerin kullandı̆ı klasik ve } \\
\text { elit bir giyim tarzmı yansitmakladır. }\end{array}$ & 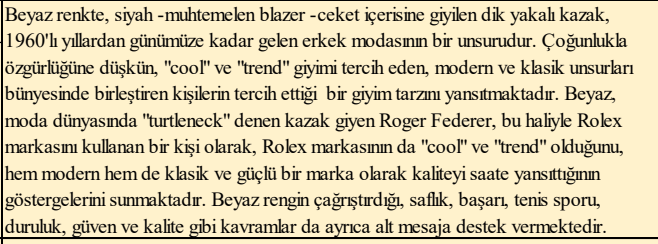 \\
\hline $\begin{array}{l}\text { FEDERER VE } \\
\text { RAKET } \\
\text { HAREKETI }\end{array}$ & $\begin{array}{l}\text { BEYAZ } \\
\text { RENKTE } \\
\text { GIYIMLI } \\
\text { FEDERER VE } \\
\text { RAKETLE TOPA } \\
\text { VURMA ANI }\end{array}$ & \begin{tabular}{|l|} 
Tenis topuna vurma anmm hareket \\
dinamig̈ini yansitan efektle zenginleşmiş, \\
hrrs ve azim ifadesi ile bakan Roger \\
Federer görüntüsü.
\end{tabular} & 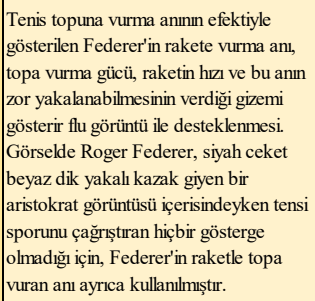 & 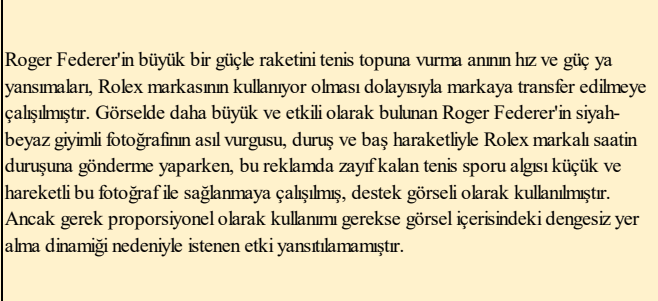 \\
\hline YEŞiL & RENK & $\begin{array}{l}\text { Rolex markas kurumsal renklerinden } \\
\text { birisi. (Diğer renk altm sarısı.) }\end{array}$ & \begin{tabular}{|l|} 
Rolex markasmm kurumsal rengi olan \\
yeşil renk, kalı bir bant şeklinde zemin \\
rengi olarak reklam görselinin alt kısmmna \\
yerleștirimiștir. Bu yeșil renk zemine \\
ayrica Rolex marka saat görseli \\
yerleștirilmiş̧ir.
\end{tabular} & $\begin{array}{l}\text { Renk dilinde yeşil renk, refah, doğalllk, doğa, zenginlik, pozitif duygular, bereket ve } \\
\text { finans dünyasmı temsil etmektedir. Rolex markasınnn kurumsal renk olarak yeşil rengi } \\
\text { seçmesi de simgesel olarak, Rolex markası seçildiği takdirde marka ile özdeşleşen söz } \\
\text { konusu çağrısımlarn kazanlacağı mesajmı vermektedir. }\end{array}$ \\
\hline
\end{tabular}

\section{Marka İletişiminde İtibar Unsurlarının İncelendiği Alan Araştırması}

\section{Alan Araştırmasının Çerçevesi}

\section{Araştırmanın Adı: Dijital Ortamda Marka İmajı}

Araştırmasının Konusu: Araştırmanın konusu maka imajını güçlendirmek amacıyla yapılan reklamlarda ünlü kullanılmasının marka imajına ve itibarına etkisini değerlendirmektir.

Araştırmanın Amacı: Araştırmanın amacı dijital ortamda kullanılan reklamlarda özellikle lüks markalardaki görsellerde kullanılan ünlülerin markanın imaj ve itibarına katkısını tüketici algısında anlamaktır. $\mathrm{Bu}$ doğrultuda lüks kategorideki markaların reklamlarının tüketici üzerindeki etkisi; reklamların online sitelerden satın almayı tetikleyici etkisi olup olmadığı; markaların reklam stratejilerinde ünlü kullanımının imajlarına nasıl etki ettiği ve reklamda ünlü kullanımının marka itibarına etkisi sorunsallarının cevaplanması hedeflenmektedir.

Araştırmanın Kapsamı: Araştırmanın kapsamı genel olarak markaların dijitalde kullandıkları reklamlarının tüketicilerde yarattı̆̆ 1 imaj etkisi ve itibar algısının incelenmesidir. Söz konusu kapsamı derinlemesine incelemek üzere Rolex markasının yüzü olan Roger Federer'in kullanıldığı dijital reklam afişlerinin markanın imajına ve itibarına etkisi üzerine bir araştırma kapsamı çerçevelenmiştir.

Araştırmanın Yöntemi: Alan araştırmasında, nitel araştırma yöntemi olarak veri toplama tekniği (anket) ve verilerin analizi yöntemi kullanılmıştır. Veriler, elektronik ortamda SurveyMonkey Online Anket Portalı ile gerçekleştirilerek, tanımsal istatistikler kullanılmıştır. Ankete katılanlara, SurveyMonkey programında kullanılan çoktan seçmeli, kapalı uçlu ve açık uçlu sorular ile toplam 25 soru yöneltilmiştir.

Alan araştırmasında elde edilen veriler doğrultusunda göstergelerin katılımcılar açısından nasıl anlamlar çağrıştırdığının gözlemlenmesi amaçlanmıştır. Bu doğrultuda soru akışında katılımcılardaki çağrışımları anlamak amacıyla açık uçlu ve göstergelerin yaygın etkilerinin gözlemlenmesi amacıyla da kapalı uçlu sorular kullanılmıştır. 
Soruların cevaplarının değerlendirilmesi 1999 yılından bugüne hizmet veren SurveyMonkey Online Anket Portalının otomatik analiz ve değerlendirme yapan grafik altyapısı ile gerçekleştirilmiştir.

Araştırmanın Örneklemi: Araştırmanın örneklemi, tesadüfi olmayan, yargısal (kasıtlı/iradi) örnekleme yöntemi kullanılarak tespit edilen Türkiye'de yaşayan, sosyal medya hesabı bulunan ve aktif kullanıcı olan kişiler tercih edilerek toplam 418 kişiyi kapsayan kadın ve erkeklerdir. Araştırmaya 21 Nisan 2020 ile 19 Mayıs 2020 tarihleri arasında gerçekleştirilmiştir.

Araştırmanın Sınırlıkları: Araştırmada örnek tema olarak Rolex markası özelinde ve Rolex markasının Roger Federer'in yer aldığ 3 adet dijital platformlarda kullanılan reklam görseli ile sınırlı reklam çalışması üzerinden yanıtlar toplanmıştır. Veriler nitel çıkarımlara ulaşmak amacıyla değerlendirilmiş olup, anlamlı nicel ifadeler içermemesi ve verilerin online araçlarla toplanması açısından sınırlıdır.

\section{Alan Araştırmasının soruları ve bulguları:}

Araştırmaya 418 kişi katılmıştır. Bu katılımcıların demografik özelliklerine dair sorulan ilk 5 (beş) soruya verilen cevaplara göre bulgular şöyledir:

Araştırmaya katılanlardan 263 kişi kadın, 151 kişi erkek, 4 kişi diğer cinsiyet seçeneğini işaretlemiştir. Buna göre araştırmaya katılanların \%62, 92’lik bir kısmı kadın katılımcılardan oluşmaktadır.

Bununla birlikte, araştırmaya katılanlardan 88 kişi 18-25 yaş aralığında; 126 kişi 26-35 yaş aralığında; 83 kişi 36-55 yaş aralığında; 82 kişi 46-55 yaş aralığında; 35 kişi 56-65 yaş aralığında ve 6 işi de 66 yaş ve üzeri yaş gurubunda olduğunu belirtmiştir. Bu bilgiler doğrultusunda katılımcıların \%30, 14'ü 26-35 yaş aralığına \%21,05'i 18-25 yaş aralığında \%19,86'sı 36-45 yaş aralığında ve \%19,62'si de 46-55 yaş aralı̆̆ında olduklarını belirtmiş bulunmaktalar.

Araştırmaya katılanların eğitim durumlarına bakıldığında ise 240 kişinin üniversite mezunu; 118 Kişinin yüksek lisans ve doktora mezunu; 33 kişinin orta öğretim mezunu; 27 kişinin yüksek okul mezunu olduğu görülmektedir. İlkokul mezunu ve eğitim almadığını belirten katılımcı olmamıştır. Bu bilgiler doğrultusunda araştırmaya katılanların \%57,42'lik bir bölümünün üniversite mezunu olduğu, \%28,23'lük bölümünün yüksek lisans ve doktora eğitimi aldığı görülmektedir.

Alan araştırmasına katılanlardan 155 kişi özel sektör çalışanı olduğunu belirtirken, 75 kişi öğrenci olduğunu, 63 kişi serbest meslek çalışanı olduğunu, 41 kişi memur olduğunu, 37 kişi emekli olduğunu, 10 kişi ev hanımı olduğunu, 37 kişi de çalışmadığını belirtmiştir. Bu bilgilere göre de araştırmada \%37, 08 oranında özel sektör çalışanı, \%17, 94 oranında öğrenci ve \%15,07 oranında serbest meslek çalışanı şeklinde çoğunluklu bir dağılım gerçekleşmiştir.

Alan araştırmasında 5. Soru olarak gelir durumları sorulan katılımcılardan 175 kişi aylık gelirinin altı bin TL ve üzeri olduğunu söylemiş, daha sonra da sırasıyla gelir durumları şu şekilde belirtilmiştir: 78 kişi dört bin ve altı bin TL arası; 77 kişi iki bin ve dört bin TL arası, 63 kişi sıfır ve bin TL aras1, 25 kişi bin ve iki bin TL arası olduğunu söylemiştir. Bu rakamlara göre katılımcıların \%41, 87'si altı bin TL ve üzeri aylık gelire sahipken, \%18,66's1 dört bin ve altı bin TL aras1 \%18,42'si ise iki bin ve dört bin TL aras1 aylık gelire sahip oldukları ortaya çıkmaktadır.

\section{Demografik sorulara verilen cevaplar, bu alan araştırmasına katılanların B, B1 ve C1 Sosyo Ekonomik Statüye sahip bir kitleden oluştuğunu bizlere göstermektedir.}

Araştırmanın 6. Sorusundan itibaren katılımcıların tüketim ve pazarlama alışkanlıklarına ilişkin sorular yöneltilmiştir. 


\section{Soru 6: Kişisel giderleriniz için ayda ne kadarlık bir harcama yapmaktasınız?}

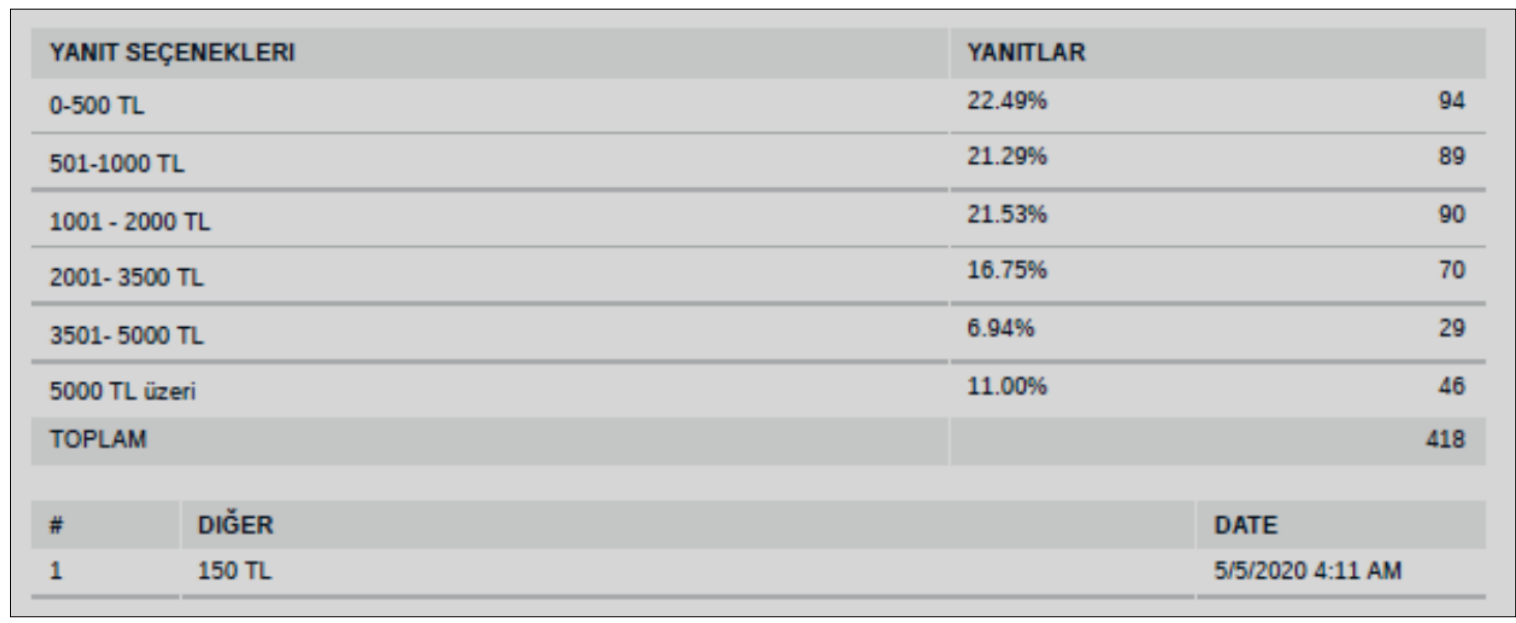

Bir kişi, 150 TL'lik kişisel harcama yaptığını belirtirken, 94 kişi \%22,49'luk oranla 0-500 TL arasında, 90 kişi \%21,53 oranıyla 1001-2000 TL arasında, 89 kişi \%21,29 oranıla 501-1000 TL arasında, 70 kişi $\% 16,75$ oranıyla 2001-3500 TL arasında, 29 kişi 6,94 oranıyla 3501-5000 TL arasında ve 46 kişi \%11 oranıyla ayada $5000 \mathrm{TL}$ ve üzeri miktarda bir harcamada bulunduğunu belirtmiştir. Bu bulgular doğrultusunda ankete katılan kişilerin çoğunluğunun $500 \mathrm{TL}$ ile $3.500 \mathrm{TL}$ aralığında aylık kişisel harcamalarda bulunduklarını, dolayısıyla ankete katılanların çoğunluğunun kişisel harcama yapma eğiliminde ve maddi gücünde olduğunu söyleyebiliriz.

Soru 7: Satın aldığınız ürünlerin markaları sizin için önemi midir?

\begin{tabular}{|c|c|c|}
\hline YANIT SEÇENEKLERI & YANITLAF & \\
\hline Evet & $45.45 \%$ & 190 \\
\hline Hayır & $5.26 \%$ & 22 \\
\hline Bazen & $49.28 \%$ & 206 \\
\hline TOPLAM & & 418 \\
\hline
\end{tabular}

Bu soruya verine yanıtlar, katılımcıların "Bazen” yanıtı ile 206 kişi, \%49,28 oranını oluştururken, "Evet" yanıtıyla 190 kişi ile \%45,45'lik bir kısmını kapsamaktadır. \%5,26’lık bir oranla 22 kişi markaların kendileri için önemli olmadığını belirtmiştir. Bu bulgular doğrultusunda, "hayır" yanıtı verenlerin azlığı dikkate alındığında markalı ürünlerin daha çok tercih edildiğini söylemek mümkündür.

\section{Soru 8: Aşağıdaki ürünleri satın alırken, markalı ürünler olmasına dikkat etmenizin derecesi nedir?}

$\mathrm{Bu}$ soruda katılımcılara Likert ölçeği ile hangi ürün grubunun markalı olmasının kendileri için önemli olduğunu belirmeleri istenirken, 245 kişi \%60,77 oranında elektronik ve teknolojik ürünlerin markalarının kendileri için kesinlikle önemli olduğunu belirtirken; daha sonra sırasıyla dayanıklı tüketim ürünlerinin ve yiyecek/gıda ürünlerinin önemli olduğunu belirtmişlerdir. Mücevher/Aksesuar ürün grubu en çok hiç önemli değildir cevabı verilen ürünler olmuştur. $\mathrm{Bu}$ bulgular doğrultusunda, tüketicilerin, günlük kullanımda bulundukları teknoloji içeren ürünler ile gıda ürünlerinde markalı ürünleri tercih etmelerine rağmen, giyim, aksesuar, temizlik ve kişisel bakım ürünlerinde ürünlerin markalı olmalarına daha az önem verdiklerini söyleyebiliriz. 


\begin{tabular}{|c|c|c|c|c|c|c|c|}
\hline & KESINLIKLE ÖNEMLIDIR & ÖNEMLIDIR & $\begin{array}{l}\text { NE } \\
\text { ÖNEMLIDIR, } \\
\text { NE ÖNEMLI } \\
\text { DEG̈ILDIR }\end{array}$ & $\begin{array}{l}\text { ÖNEMLI } \\
\text { DEGILDIR }\end{array}$ & $\begin{array}{l}\text { HIIC } \\
\text { ÖNEMLI } \\
\text { DEĞILDIR }\end{array}$ & TOPLAM & $\begin{array}{l}\text { AĞIRLIKI } \\
\text { ORTALAI }\end{array}$ \\
\hline $\begin{array}{l}\text { Yiyecek/Gıda } \\
\text { UUrūnleri }\end{array}$ & $\begin{array}{r}41.87 \% \\
175\end{array}$ & $\begin{array}{r}45.22 \% \\
189\end{array}$ & $\begin{array}{r}8.85 \% \\
37\end{array}$ & $\begin{array}{r}2.87 \% \\
12\end{array}$ & $\begin{array}{r}1.20 \% \\
5\end{array}$ & 418 & 1 \\
\hline Giyim Ürünleri & $\begin{array}{r}11.24 \% \\
47\end{array}$ & $\begin{array}{r}36.36 \% \\
152\end{array}$ & $\begin{array}{r}36.84 \% \\
154\end{array}$ & $\begin{array}{r}9.57 \% \\
40\end{array}$ & $\begin{array}{r}5.98 \% \\
25\end{array}$ & 418 & 2 \\
\hline $\begin{array}{l}\text { Hizmet Sektōrü } \\
\text { Ūrūnleri }\end{array}$ & $\begin{array}{r}20.33 \% \\
85\end{array}$ & $\begin{array}{r}52.15 \% \\
218\end{array}$ & $\begin{array}{r}20.81 \% \\
87\end{array}$ & $\begin{array}{r}4.78 \% \\
20\end{array}$ & $\begin{array}{r}1.91 \% \\
8\end{array}$ & 418 & 2 \\
\hline $\begin{array}{l}\text { Dayanıklı Tüketim } \\
\text { Malzemeleri } \\
\text { Ürūnleri }\end{array}$ & $\begin{array}{r}47.37 \% \\
198\end{array}$ & $\begin{array}{r}45.93 \% \\
192\end{array}$ & $\begin{array}{r}5.02 \% \\
21\end{array}$ & $\begin{array}{r}1.44 \% \\
6\end{array}$ & $\begin{array}{r}0.24 \% \\
1\end{array}$ & 418 & 1 \\
\hline $\begin{array}{l}\text { Elektronik/Teknolojik } \\
\text { Ürünler }\end{array}$ & $\begin{array}{r}60.77 \% \\
254\end{array}$ & $\begin{array}{r}34.21 \% \\
143\end{array}$ & $\begin{array}{r}3.83 \% \\
16\end{array}$ & $\begin{array}{r}0.96 \% \\
4\end{array}$ & $\begin{array}{r}0.24 \% \\
1\end{array}$ & 418 & 1 \\
\hline $\begin{array}{l}\text { Mücevher/Aksesuar } \\
\text { Ürünleri }\end{array}$ & $\begin{array}{r}11.48 \% \\
48\end{array}$ & $\begin{array}{r}22.01 \% \\
92\end{array}$ & $\begin{array}{r}32.78 \% \\
137\end{array}$ & $\begin{array}{r}19.86 \% \\
83\end{array}$ & $\begin{array}{r}13.88 \% \\
58\end{array}$ & 418 & 3 \\
\hline $\begin{array}{l}\text { Temizlik/Hijyen } \\
\text { Ürünleri }\end{array}$ & $\begin{array}{r}29.43 \% \\
123\end{array}$ & $\begin{array}{r}43.54 \% \\
182\end{array}$ & $\begin{array}{r}17.22 \% \\
72\end{array}$ & $\begin{array}{r}6.94 \% \\
29\end{array}$ & $\begin{array}{r}2.87 \% \\
12\end{array}$ & 418 & 2 \\
\hline $\begin{array}{l}\text { Kişisel } \\
\text { Bakım/Makyaj } \\
\text { Ürünleri }\end{array}$ & $\begin{array}{r}40.67 \% \\
170\end{array}$ & $\begin{array}{r}42.58 \% \\
178\end{array}$ & $\begin{array}{r}12.68 \% \\
53\end{array}$ & $\begin{array}{r}1.91 \% \\
8\end{array}$ & $\begin{array}{r}2.15 \% \\
9\end{array}$ & 418 & 1 \\
\hline
\end{tabular}

Soru 9: Satın aldığınız ürün markasının reklam yüzü/tanıtım yüzü hoşlanmadığınız bir sanatçı/sporcu/ünlü ise bu size ne hissettirir?

\begin{tabular}{|c|c|c|}
\hline YANIT SEÇENEKLERI & \multicolumn{2}{|c|}{ YANITLAR } \\
\hline Markanın iletişim çalıșmasını yanııș yaptığııı dūşūnürūm, ancak satın almaya devam ederim. & $31.82 \%$ & 133 \\
\hline Markanın iletişim çalıșmasını yanlış yaptığıı dūşūnürūm, ancak satın almaya devam etmem. & $7.42 \%$ & 31 \\
\hline Marka ile kendimi uyumsuz bulurum, ancak satın almaya devam ederim. & $11.24 \%$ & 47 \\
\hline Marka ile kendimi uyumsuz bulurum, ancak satın almaya devam etmem. & $6.70 \%$ & 28 \\
\hline İmajımla daha uyumlu iletişim çalıșması yapan yeni bir marka arayışına girerim, bu markayı satın almam. & $8.37 \%$ & 35 \\
\hline Benim için hiçbir önemi yoktur, markayı imajı için seçmem. & $34.45 \%$ & 144 \\
\hline TOPLAM & & 418 \\
\hline
\end{tabular}

Bu soruya 144 kişi "benim için önemi yoktur" derken, 133 kişi "markanın iletişim çalışmasını yanlış yaptığını düşünür ancak satın almaya devam ederim" demiştir.

35 kişi imajı daha uygun marka arayışına girerek bu markayı satın almayacağını söylemiştir.

Ancak toplamda çeşitli cevaplar bazında 324 kişi markayı satın almaya devam edeceğini belirtirken, 94 kişi markayı satın almayacağını ifade etmiştir.

Tüketiciler, genel olarak markanın reklam yüzünden hoşlanmadıklarında söz konusu markayı satın almaya devam edebileceklerini belirterek, reklam yüzünün markayı satın alma isteğine etkisinden çok yanlış bir iletişim çalışması yaptığını düşüneceklerini belirtmişlerdir. 


\section{Soru 10: Markaların reklamlarında en çok dikkat ettiğiniz unsurun önem derecesi nedir?}

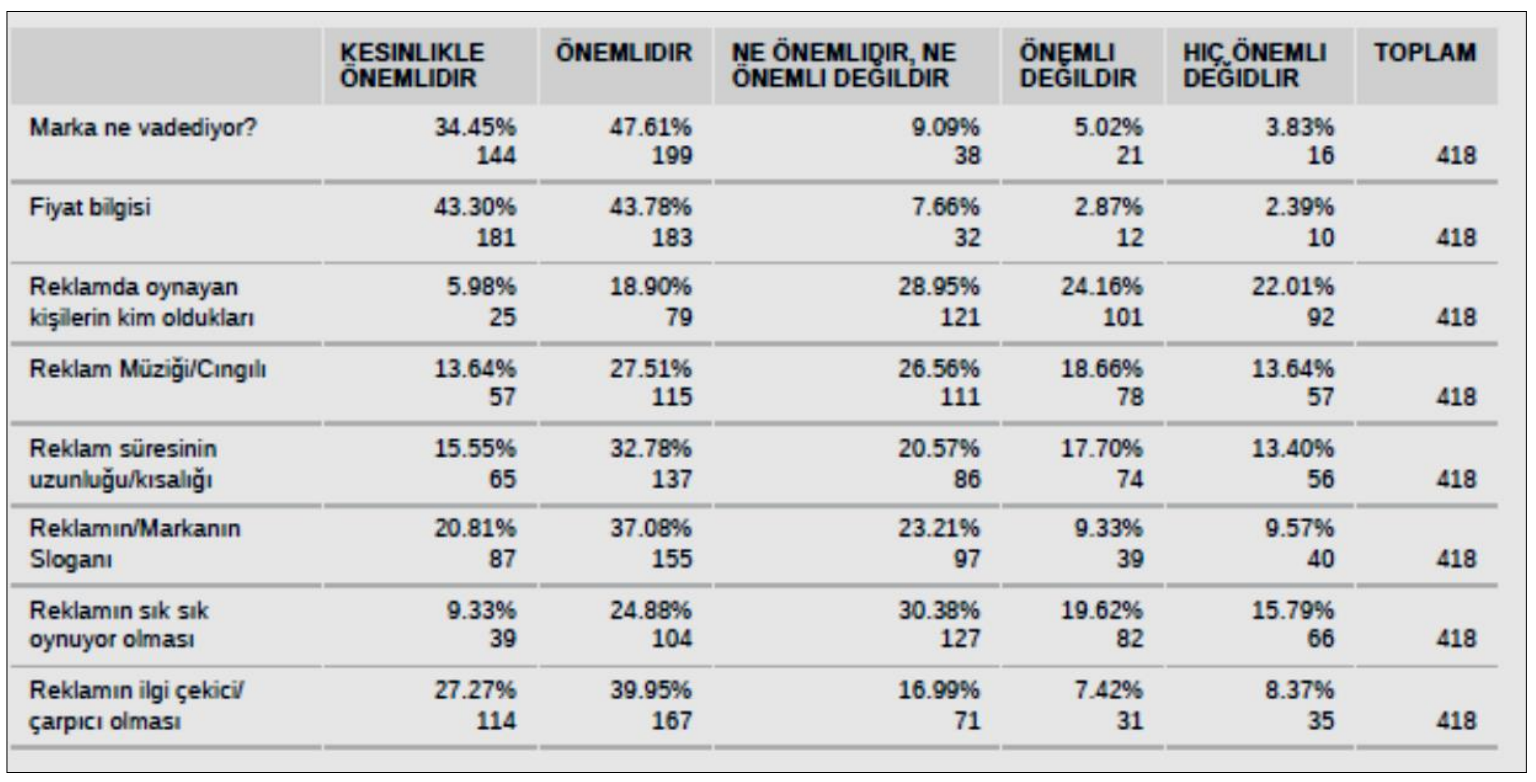

Tüketiciler reklamlarda en çok dikkat ettikleri unsurların neler olduğunun yöneltildiği bu soruda en çok 181 kişi ile ve $\% 43,30$ oranı ile kesinlikle önemlidir, 183 kişi ve $\% 43,78$ oranı ile önemlidir seçeneğini seçerek fiyat bilgisinin; daha sonra da 144 kişi ile \%34,45 oranında marka vaadinin, 114 kişi ve \%27,27 oranı ile de reklamın ilgi çekici çarpıcı olması kriterleri cevap olarak seçilmiştir. Ayrıca 92 kişi \%22,01 oranı ile reklamlarda oynayan kişilerin hiç önemli olmadığını belirtmiştir.

$\mathrm{Bu}$ sorudan elde edilen bulgular doğrultusunda, ürünün fiyat bilgisinin her koşulda kesinlikle önemli olduğu ortaya çıkarken, daha sonra markanın vaadi ve sonrasında da reklam içeriklerine ilişkin etkilerin dikkate alındığını söyleyebiliriz.

Soru 11: Marka tercihlerinizi belirlerken, sevdiğiniz bir ünlünün kullandığı marka mı; yoksa aile ferdi/arkadaş gibi yakın bir tanıdığınızın kullandığı marka mı sizce daha önemli olur?

\begin{tabular}{|l|rr|}
\hline YANIT SEÇENEKLERI & \multicolumn{2}{|l|}{ YANITLAR } \\
\hline Aile ferdi/arkadaș gibi yakın bir tanıdığımın kullandığı marka & $61.96 \%$ & 259 \\
\hline Sevdiğim ünlünũn kullandığı marka & $2.15 \%$ & 9 \\
\hline Her ikisi de & $15.07 \%$ & 63 \\
\hline Hiçbiri & $20.81 \%$ & 87 \\
\hline TOPLAM & & 418 \\
\hline
\end{tabular}

Marka tercihlerinde danışma gurubu olarak kimlerin tercih edildiğine yönelik bu soruda a259 kişi \%61,96 oranında ürünü kullanan tanıdıklarının referans alındığını belirtirken, 9 kişi \%2,15 oranında sevilen bir ünlünün referans alındığını belirtmiştir.

$\mathrm{Bu}$ soruya verilen yanıtlara göre, tüketicilerin reklamlarda kullandıkları maka yüzlerinin satın alma aşamasında doğrudan etkili olmadığını söyleyebiliriz. Tüketiciler, birinci dereceden tanıdıkları kişileri referans alarak satın almada bulunmaktadırlar diyebiliriz. 
Soru 12: Sevdiğiniz, hayranı olduğunuz bir sanatçı/sporcu/ünlü yepyeni bir markanın reklam/tanıtım yüzü olduğunda, en az bir kez o yeni ürünü satın alma eğiliminiz olur mu?

\begin{tabular}{|c|c|c|}
\hline YANIT SEÇENEKLERI & YANITLAR & \\
\hline Evet & $14.35 \%$ & 60 \\
\hline Hayır & $49.04 \%$ & 205 \\
\hline Bazen & $36.60 \%$ & 153 \\
\hline TOPLAM & & 418 \\
\hline
\end{tabular}

Ünlülerin marka yüzü olmaları konusundaki tüketici eğilimini ölçmede pekiştirici soru olarak yöneltilen bu soruya verilen yanıtlar 205 kişi ve \%49,04 oranında marka tercihinde ünlünün etkisinin olmadığını belirtmiştir. Ancak 153 kişi \%36,60 oranında bazen ünlünün marka tercihinde etkili olduğunu da belirmiştir.

$\mathrm{Bu}$ soruya verilen yanıtlara göre, ünlü kullanımının marka seçimine doğrudan etkisi olmadığını ancak bazı durumlarda da ünlünün markayı kullanmaya yönlendirebileceğini söyleyebiliriz.

\section{Soru 13: Roger Federer isimli ünlüyü tanıyor musunuz?}

\begin{tabular}{|c|c|c|}
\hline YANIT SEÇENEKLERI & YANITLAF & \\
\hline Evet & $65.07 \%$ & 272 \\
\hline Hayır & $27.27 \%$ & 114 \\
\hline Duydum ama tanımıyorum & $7.66 \%$ & 32 \\
\hline TOPLAM & & 418 \\
\hline
\end{tabular}

Araştırmaya katılan 272 kişi \%65,07 oranı ile Roger Federer'in kim olduğunu bildiği bilgisini vermiştir. Dolayısıyla Roger Federer'in, araştırmaya katılan kişilerin çoğunluğu tarafindan bilinen bir ünlü olduğunu söyleyebiliriz.

Soru 14: Roger Federer aşağıdaki markalardan hangisinin tanıtım/reklam yüzüdür?

\begin{tabular}{|c|c|c|}
\hline YANIT SEÇENEKLERI & YANITLAR & \\
\hline Armani & $0.33 \%$ & 1 \\
\hline Rolex & $24.00 \%$ & 72 \\
\hline Oscar De La Renta & $0.00 \%$ & 0 \\
\hline Ralph Lauren & $0.67 \%$ & 2 \\
\hline Hugo Boss & $1.00 \%$ & 3 \\
\hline Hepsi & $0.67 \%$ & 2 \\
\hline Hiçbiri & $4.67 \%$ & 14 \\
\hline Bilmiyorum / Emin Değilim & $68.67 \%$ & 206 \\
\hline TOPLAM & & 300 \\
\hline
\end{tabular}

Bu soru ile Roger Federer'in kim olduğu bilinmesine rağmen, Rolex markasının yüzü olduğunu bilmeyen ve araştırmaya katılan 206 kişinin \%68,67 oranında olduğu, yalnızca 72 kişinin \%24,00 oranı ile Rolex'in marka yüzü olduğunu bildiğini belirttiği ortaya çıkmıştır. Araştırmaya katılan kişilerin, Roger Federer'i 
ağırlıklı olarak tanımalarına rağmen Rolex markasının reklam yüzü olduğunu çoğunlukla bilmediklerini söyleyebiliriz.

Soru 15: Değeri çok yüksek olan bir aksesuar veya mücevheri e-ticaret sitesinden satın alır mısınız?

\begin{tabular}{|c|c|c|}
\hline YANIT SEÇENEKLERI & YANITLAR & \\
\hline Evet & $14.98 \%$ & 62 \\
\hline Hayır & $85.02 \%$ & 352 \\
\hline TOPLAM & & 414 \\
\hline
\end{tabular}

Rolex markasının lüks ve pahalı bir ürün olması nedeniyle, dijital ortamda satın alınmasının mümkün olup olmadığına yönelik ilk adım sorusu olarak yöneltilen bu soruya tüketiciler, 352 kişi ve \%85,02 oranı ile pahalı ürünleri internetten satın almayacaklarını belirtmişlerdir. Dolayısıyla, e-ticaret sitelerinden pahalı ürün satın alınmasına yönelik tüketicilerde bir çekince olduğu bulgusunun elde edildiğini söyleyebiliriz.

\section{Soru 16: Değeri çok yüksek olan bir aksesuar veya mücevheri e-ticaret sitesinden neden satın alırsinız?}

15. soruya "Evet" yanıtını veren tüketicilerin neden pahalı ürünleri e-ticaret sitesinden satın aldıklarının yöneltildiği bu soruya ürüne erişmek daha kolay olduğu için şeklinde yanıt veren \%33,87 oranıyla 21 kişi olurken, ikinci sırada 19 kişi \%30,65 oranı ile pratik olduğu için yanıtını vermiştir. E-ticaret sitelerinin satın alma eyleminde tercih edilmesinde "kolaylık" faktörünün etkin olduğunu söyleyebiliriz.

\begin{tabular}{|c|c|c|}
\hline YANIT SEÇENEKLERI & \multicolumn{2}{|c|}{ YANITLAR } \\
\hline Pratik olduğu için & $30.65 \%$ & 19 \\
\hline Güvenli olduğu için & $4.84 \%$ & 3 \\
\hline Ūrūne erişmek daha kolay olduğu için (fiziksel mağazası başka ülke veya bölgededir) & $33.87 \%$ & 21 \\
\hline Ūrūnü tanıdığım için kalitesinde sorun olmayacağını düşünūrüm & $25.81 \%$ & 16 \\
\hline Değișik bir alışveriş tecrūbesi olacağı için & $4.84 \%$ & 3 \\
\hline TOPLAM & & 62 \\
\hline
\end{tabular}

Soru 17: Değeri çok yüksek olan bir aksesuar veya mücevheri e-ticaret sitesinden neden satın almazsiniz?

\begin{tabular}{|l|c|}
\hline YANIT SEÇENEKLERI & YANITLAR \\
\hline Güvenli alışveriş olmayabileceği için & $34.34 \%$ \\
\hline Ūrūnü fiziksel olarak deneyerek satın almak isterim & $52.71 \%$ \\
\hline Satış esnasındaki konfor ve ayncalığı da tecrübe etmek isterim & 114 \\
\hline Lüks markalar e-ticaret sitelerinden satıș yapmadıkları için & $10.54 \%$ \\
\hline TOPLAM & $2.41 \%$ \\
\hline
\end{tabular}

15. soruya "Hayır" yanıtını veren tüketicilerin neden pahalı ürünleri e-ticaret sitesinden satın almadıklarının yöneltildiği bu soruya $\% 52,71$ oranı ile 175 kişi ürünü fiziksel olarak denemek istediklerini, 114 kişi \%34,34 oranı ile güvenli alışveriş olmayabileceğini düşündükleri yanıtlarını vermiştir. 8 kişi \%2,41 oranı ile lüks markaları e-ticaret sitesinden satın almadıklarını belirtmiştir. Araştırmaya katılanlar, ağırlıklı olarak lüks ürünleri fiziksel olarak deneyerek satın almak istediklerini belirterek, güvenli alışveriş yanlısı olduklarını belirtmişlerdir diyebiliriz. 


\section{Soru 18: Rolex markasını duydunuz mu?}

\begin{tabular}{|l|r|r|}
\hline YANIT SEÇENEKLERI & YANITLAR & 378 \\
\hline Evet & $98.18 \%$ & 7 \\
\hline HayIr & $1.82 \%$ & 385 \\
\hline TOPLAM & & 7 \\
\hline
\end{tabular}

378 kişi Rolex markasını bildiklerini, 7 kişi ise bilmediklerini belirtmişlerdir. Böylece katılımcıların \%98,18 oranında Rolex markasını bildikleri görülmüştür. Dolayısıyla Rolex markası lüks tüketim ürünü olmasına rağmen araştırmaya katılanlar tarafindan büyük çoğunlukla bilinmektedir diyebiliriz.

\section{Soru 19: Rolex markası sizce aşağıdaki hangi ürünün markasıdır?}

\begin{tabular}{|c|c|c|c|}
\hline \multirow{2}{*}{\multicolumn{2}{|c|}{$\begin{array}{l}\text { YANIT SEÇENEKLERI } \\
\text { Giyim }\end{array}$}} & \multicolumn{2}{|c|}{ YANITLAR } \\
\hline & & $0.00 \%$ & 0 \\
\hline \multicolumn{2}{|c|}{ Aksesuar } & $2.33 \%$ & 9 \\
\hline \multicolumn{2}{|c|}{ Saat } & $96.12 \%$ & 372 \\
\hline \multicolumn{2}{|c|}{ Elektronik eșya } & $0.00 \%$ & 0 \\
\hline \multicolumn{2}{|c|}{ Konaklama Hizmeti } & $0.00 \%$ & 0 \\
\hline \multicolumn{2}{|c|}{ Sağlık Hizmeti } & $0.52 \%$ & 2 \\
\hline \multicolumn{2}{|c|}{ Hiçbiri } & $0.52 \%$ & 2 \\
\hline \multicolumn{2}{|c|}{ Diğer } & $0.52 \%$ & 2 \\
\hline \multicolumn{2}{|c|}{ TOPLAM } & & 387 \\
\hline$\#$ & DIǦER & & DATE \\
\hline 1 & Kozmetik & & 5/5/2020 11:27 PM \\
\hline 2 & Şampuan & & 5/3/2020 5:43 PM \\
\hline
\end{tabular}

19. soru ile Rolex markasının \%96,12 oranlık bir katılım ve 372 kişi olarak bir saat markası olduğunun bilindiği ortaya çıkmıştır. Dolayısıyla Rolex markasının saat sektöründe bir marka olduğu da bilinmektedir.

\section{Soru 20: Rolex markalı bir ürün satın aldınız mı?}

\begin{tabular}{|l|lr|}
\hline YANIT SEÇENEKLERI & YANITLAR & 36 \\
\hline Evet & $9.33 \%$ & 350 \\
\hline HayIr & $90.67 \%$ & 386 \\
\hline TOPLAM & & 38 \\
\hline
\end{tabular}

Araştırmaya katılanların \%90,67 oranı ile ve 350 kişi ile Rolex markası bir saat sahibi olmadıkları görülmüştür. 36 Kişinin ise Rolex markalı bir ürün satın aldıklarını ifade ettikleri görülmüştür. Bu soruya verilen yanıtlara göre, katılımcıların çoğunluğunun Rolex markalı bir ürün satın almadığını söyleyebiliriz. 
Soru 21: Lüks bir markanın tanıtım/reklam yüzü olan sanatçı/sporcu/ünlü kişi sizce markaya ne kazandırır?

\begin{tabular}{|l|r|r|}
\hline YANIT SEÇENEKLERI & YANITLAR & 84 \\
\hline Tanınmışlık & $21.71 \%$ & 18 \\
\hline Kalite & $4.65 \%$ & 52 \\
\hline İtibar & $13.44 \%$ & 91 \\
\hline Bilinirlik & $23.51 \%$ & 27 \\
\hline Güven & $6.98 \%$ & 0 \\
\hline Sadakat & $0.00 \%$ & 32 \\
\hline Seçkinlik & $8.27 \%$ & 42 \\
\hline Hepsi & $10.85 \%$ & 31 \\
\hline Hiçbiri & $8.01 \%$ & 10 \\
\hline Diğer (lütfen belirtin) & $2.58 \%$ & 387 \\
\hline TOPLAM & & 32 \\
\hline
\end{tabular}

\section{Diğer cevapları:}

\begin{tabular}{|c|c|c|}
\hline$\#$ & DIĞER (LÜTFEN BELIRTIN) & DATE \\
\hline 1 & Farkindalik & 5/7/2020 11:01 PM \\
\hline 2 & hatirlanma & 5/5/2020 10:58 PM \\
\hline 3 & Kullanıma Ōzendirme & 5/5/2020 10:56 PM \\
\hline 4 & $\mathrm{E}$ & 5/5/2020 12:00 AM \\
\hline 5 & Hiçbirşey kazandırmaz, aksine kaybettirir & 5/4/2020 11:20 PM \\
\hline 6 & 7 & 5/4/2020 11:20 AM \\
\hline 7 & $\begin{array}{l}\text { Insanlara eğer o ürünü alırlarsa reklamda oynayan kişiler gibi olacağına dair bir kanı } \\
\text { kazandırır. Bu da markayla belli başlı özelliklerin özdeşleşmesine sebep olur. }\end{array}$ & 5/4/2020 11:02 AM \\
\hline 8 & L & 5/3/2020 6:58 PM \\
\hline 9 & Popūlerlik & 5/3/2020 4:02 PM \\
\hline 10 & i & 5/2/2020 7:45 PM \\
\hline
\end{tabular}

Lüks markaların, tanıtım ve reklam yüzü olarak bir ünlünün seçilmesinin markaya kazandırdıklarına ilişkin tüketicilerin görüşlerinin alındığ 1 bu soruya en çok yanıt 91 kişi ve \%23,51 oranı ile bilinirlik yanıtı verirken, 84 kişi, \%21,71 oranı ile tanınmışlık cevabını vermiştir. Tüm seçeneklerin kabul edildiği hepsi cevabını ise 42 kişi $\% 10,85$ oranı ile cevaplamıştır. Markaya hiçbir şey kazandırmadığını düşünenlerin oranı ise \%8,01 oranı ile 31 kişi iken açık uçlu cevaplar verenler de olmuştur.

Verilen yanıtlar dikkate alındığında, bir markanın tanınmış bir kişiyi reklam yüzü olarak kullanmasının markanın bilinirlik ve tanınırlığına ağırlıklı olarak yardımcı olduğunu söyleyebiliriz. Öte yandan tanınmış kişinin markaya itibar kazandırdığı da cevaplar arasında yer alırken, "hepsi” seçeneği seçen kişiler de göz önünde bulundurulduğunda, ünlünün markaya güven, seçkinlik, sadakat ve kalite kazandıracağını düşünenlerin de olduğunu söyleyebiliriz.

Rolex markasının dijital ortamlarda kullandı̆̆ı Roger Federer'in bulunduğu reklamlarından tesadüfi olmayan şekilde seçilen 4 ayrı reklamının incelendiği 22, 23, 24 ve 25. Soruların cevaplarının dĕgerlendirildiği tablolar aşağıda yer almaktadır. 
Soru 22: Yukarıdaki görsel en çok dikkatinizi çeken obje/unsur nedir?

Yanit: 387 Atlanan:31

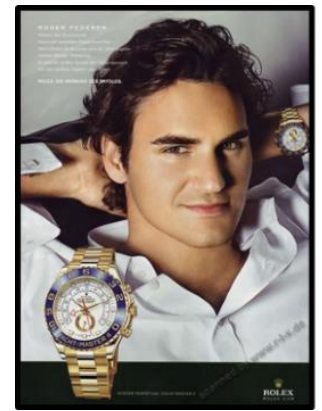

\begin{tabular}{|l|c|c|}
\hline $\begin{array}{l}\text { DİKKAT ÇEKEN } \\
\text { UNSUR }\end{array}$ & KİŞİ SAYISI & YÜZDE (\%) \\
\hline ROLEX SAAT & $\mathbf{2 6 6}$ & $\mathbf{6 8 , 7 3 \%}$ \\
\hline ROGER FEDERER & $\mathbf{8 5}$ & $\mathbf{2 1 , 9 6 \%}$ \\
\hline DİĞER & 36 & 9,3 \\
\hline TOPLAM & 387 & \\
\hline
\end{tabular}

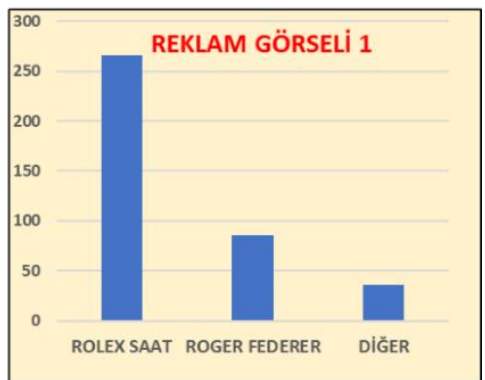

Reklamda "Rolex markalı saat" 266 kişi tarafından \%68,73 oranında dikkat çekmiştir.

Soru 23: Soru 22: Yukarıdaki görsel en çok dikkatinizi çeken obje/unsur nedir?

Yanit: 387 Atlanan:31

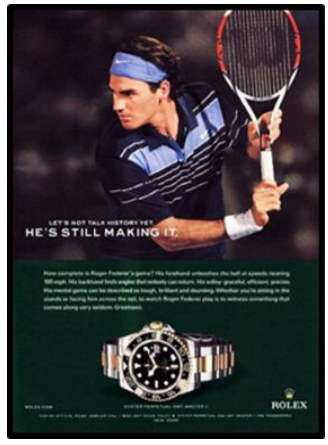

\begin{tabular}{|l|c|c|}
\hline $\begin{array}{l}\text { DİKKAT ÇEKEN } \\
\text { UNSUR }\end{array}$ & KİŞİ SAYISI & YÜZDE (\%) \\
\hline ROLEX SAAT & 61 & $15,76 \%$ \\
\hline ROGER FEDERER & 49 & $12,66 \%$ \\
\hline RAKET & 162 & $41,86 \%$ \\
\hline NIKE & 21 & $5,42 \%$ \\
\hline DİĞER & 94 & $24,28 \%$ \\
\hline TOPLAM & 387 & \\
\hline
\end{tabular}

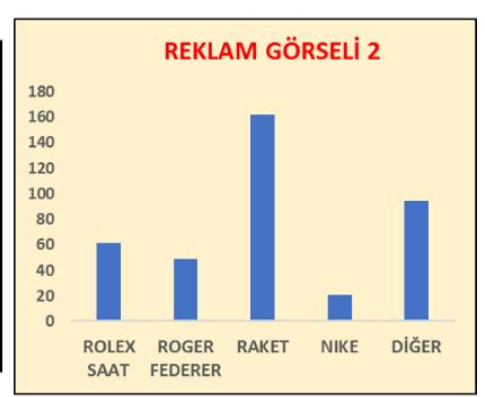

$\mathrm{Bu}$ sorudaki reklamda, Raket, \%41,86 oranı ile 162 kişi tarafindan dikkat çeken unsur olarak belirtilmesine rağmen, Rolex Saat 61 kişi tarafından \%15,76 oranında dikkat çeken unsur olarak belirtilmiştir.

Soru 24: Soru 22: Yukarıdaki görsel en çok dikkatinizi çeken obje/unsur nedir?

Yanit: 387 Atlanan:31

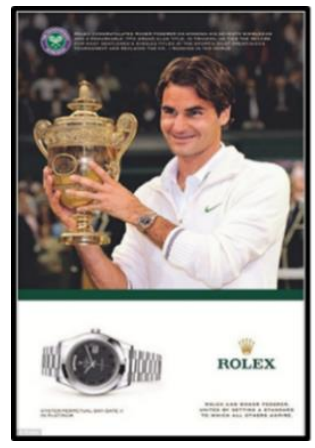

\begin{tabular}{|l|c|c|}
\hline $\begin{array}{l}\text { DİKKAT ÇEKEN } \\
\text { UNSUR }\end{array}$ & KİŞİ SAYISI & YÜZDE (\%) \\
\hline ROLEX SAAT & 65 & $16,79 \%$ \\
\hline ROGER FEDERER & 20 & $5,16 \%$ \\
\hline KUPA & 257 & $66,40 \%$ \\
\hline DİĞER & 45 & $11,66 \%$ \\
\hline TOPLAM & 387 & \\
\hline
\end{tabular}

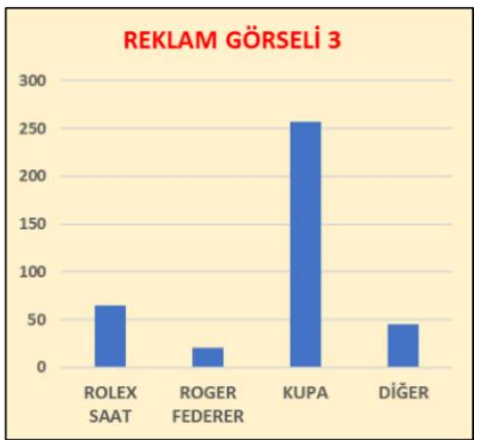

Bu sorudaki reklamda katılımcılar, en çok 257 kişi olarak \%66,40 oranında görseldeki Kupanın dikkat çekici olduğunu belirtmişlerdir. Rolex saat ise \%16,70 oranı ve 65 kişi ile dikkat çekici unsur olarak yanıtlanmıştır. 


\section{Soru 25: Soru 22: Yukarıdaki görsel en çok dikkatinizi çeken obje/unsur nedir? Yanit: 387 Atlanan:31}

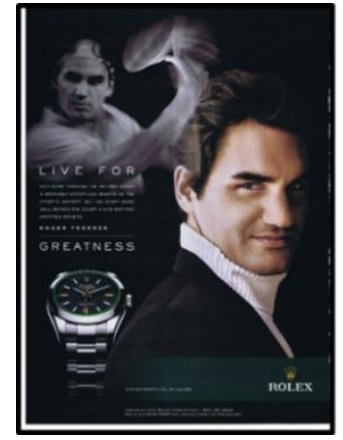

\begin{tabular}{|l|c|c|}
\hline $\begin{array}{l}\text { DİKKAT ÇEKEN } \\
\text { UNSUR }\end{array}$ & KİŞI SAYISI & YÜZDE (\%) \\
\hline ROLEX SAAT & 152 & $39,27 \%$ \\
\hline ROGER FEDERER & 90 & $23,25 \%$ \\
\hline KAZAK & 45 & $11,62 \%$ \\
\hline DİĞER & 100 & $25,83 \%$ \\
\hline TOPLAM & 387 & \\
\hline
\end{tabular}

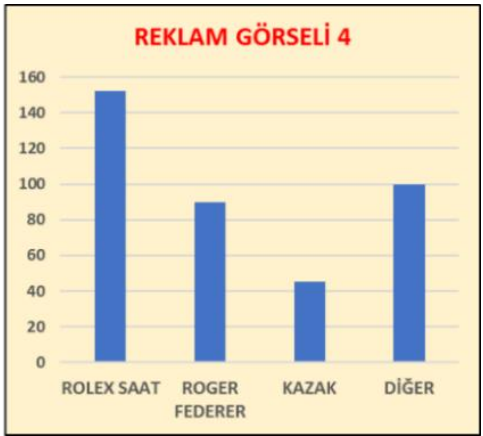

Bu soruda Rolex saat 152 kişi tarafından \%39,27 oranı ile dikkat çekici unsur olarak belirtilirken, Roger Federer \%23,25 oranı ile 90 kişi tarafindan seçilmiştir.

\section{Alan araştırması bulgularının değerlendirilmesi}

25 sorudan oluşan alan araştırmasına verilen yanıtlardan yola çıkarak, büyük oranda B ve B1 SES grubunun katıldığı tüketicilerin verdikleri yanıtlardan ağırlıklı olarak Rolex markasını ve Roger Federer ismini tanıdıkları, ancak kişi ve saat markasının birlikteliğinin ve sponsorluğunun pek bilinmediğinin ortaya çıktığını söyleyebiliriz. Öte yandan bir ünlünün kullandığı markanın ve ünlünün yer aldı̆̆ reklamın markanın tanınırlık ve bilinirliğine katkıda bulunmasına rağmen tüketiciler tarafindan satın almaya yönlendirmede çok etkili olmadığı sonucunu söylemek hiç de yanlış olmayacaktır çünkü referans grubu olarak araştırmaya katılan tüketiciler bir tanıdıklarının kullandığı ürünü satın almaya daha çok eğilimli olduklarını belirtmişlerdir. Ayrıca e-ticaret sitesinden lüks ürünlerin alışverişi yapılmasında tüketiciler güvenlik nedeniyle endişe duyduklarını belirtirken, lüks ürünleri satınalarken fiziksel olarak denemek istediklerini de ifade etmişlerdir.

Markalar ve özellikle lüks markalar dijital platformlarda kullandıkları reklamlarla tüketicilerini etkilemeye çalışmakta, reklam yüzleri olan ünlülerin itibar ve algılarının tüketicilerine aktarılmasına çalışmaktadırlar. Ancak bunu yaparken, kullandıkları reklam görsellerindeki teknik unsurlar ve seçilen görseller ile bu görsellerin perspektif, renk, büyüklük ya da yerleşim olarak çalışmada yer alana objeler, kişiler veya logolar tüketicileri etkilemektedir. Söz konusu görsel unsurların markanın beklentisini sağlayacak yönde bir etki yaratması, tüketicilerin kültür, eğitim ve hayat görüşüne göre değişmekte; aynı zamanda tüketicilerin ürüne, markaya ve ünlüye karşı geliştirdiği önyargı veya sempatiye bağlı olarak da artan ya da azalan oranda farklılıklar göstermektedir diyebiliriz.

Lüks markalar e-ticaret sitelerinden alışveriş yapılmasını dijital reklamlarla desteklemektedirler. Rolex markasının da dijital ortamdaki web sitesinde online alışveriş imkânı bulunmaktadır. Dijital ortamda lüks markaların satın alınmasına ilişkin reklam ve tanıtımlar yapılmaktadır. Ancak tüketicilerin e-ticaret sitelerine ilişkin güven sorunları ile ürünle temas etme isteklerinin, lüks ürünlerin e-ticret sitelerinden alışverişlerinin yapılmasının karşısında bir engel olduğu da görülmektedir.

Markaların reklam stratejilerinde ünlü kullanımı imajlarına olumlu etki kazandırma yönünde önemli bir çabadır. Rolex markası, Roger Federer dışında da alanında başarılı, yakışıklı veya güzel, kitlelerin dikkatini çeken, karizmatik, bilgili, seçkin tüketim alışkanlıklarına sahip kişileri reklamlarında kullanmıştır. Öte yandan, alt metinde, Roger Federer'in, tenis sporunda elde ettiği başarılar, Rolex markasının içinde bulunduğu kategoride de başarılı olduğu yönünde çeşitli söylem ve anlam göndermelerine sahiptir diyebiliriz. Tüketiciler de reklam görsellerinde bahsedilen yönde verilmek istenen anlam göndermelerini büyük ölçüde kavramışlardır.

Markaların reklam stratejilerinde ünlü kullanımı itibarlarını genel olarak olumlu yönde etkilemektedir. Marka iletişimindeki reklam görsellerinde ünlülerin yer almasının reklam çalışmalarını ne derece 
etkilediği ve dikkat çektiği, ürünün satın allanmasına etkisinin olup olmadığının bir ölçüde belirlenmesi için yöneltilen dört Rolex-Roger Federer görseline ilişkin verilen yanıtlar da oldukça dikkat çekici olmuştur. Reklamlarda ünlünün yer almasının ilk etapta reklama yöneltmede etkili olduğunu söyleyebileceğimiz yanıtlar olmasına rağmen, reklam görselindeki grafik yerleşim, kullanılan yan objeler, yazılar ve diğer görüntüler in proposiyonel ve dizayn olarak yerleşimleri renkleri, önde veya arkada yer almaları gibi teknik özelliklerin önemli olduğu açıç̧a ortaya çıkmaktadır. Özellikle, reklamı yapılan marka ve ürünün görselde etkili bir şekilde yerleşmemiş olması ve baskın başka faktörlerin olması durumunda tüketicinin ürün ve markadan çok aslında önemli olmayan diğer görsel unsurlara dikkat ettiği görülmüştür. Elde edilen bu bulgular ışığında, reklam görsellerinde ünlü kullanımının önemli olduğu ortaya çıkmasıyla beraber, ünlünün marka imajılla doğru orantılı olarak seçilmesi gerektiği ortaya çıkmaktadır. Ayrıca, reklam tasarımlarında satın almayı özendirecek ya da reklamı yapılan ürün veya markaya dikkat çekecek şekilde grafik ve görsel tasarımlar yapılmasının da çok önemli olduğu bir kez daha ortaya çıkmaktadır.

Yapılan alan araştırmasının değerlendirmesi olarak; araştırmanın, yalnızca Rolex ve Roger Federer markaları ile ilgili olarak sonuçlar içermesi ve örneklem olarak tesadüfi olmayan kasitlı örnekleme yapılmış bir araştırma olması dikkate alarak, daha geniş katılımcıların ve örneklemin ele alındığ araştırmalara kaynaklık edebileceğini ayrıca elde edilen bulguların daha derinlemesine incelenmesi gereken bir konu olduğunu ortaya çıkarttığını söyleyebiliriz.

Öte yandan, alan araştırmasında katılımcılara yöneltilen üç ayrı Rolex-Roger Federer reklam afişi ile ilgili elde edilen bulgular ile Roland Bahrates'in düzanlam-yananlam tekniği kullanılarak incelenmesi neticesinde elde edilen analiz birlikte değerlendirildiğinde, bu çalışmada elde edilen çıkarımların çok önemli olduğunu söyleyebiliriz.

Bir numaralı afiş görselinde tüketicilerin en çok dikkat ettikleri obje saattir. Tenis sporu zamanın çok iyi kullanılmasını gerektiren ve saniyelerin çok önemli olduğu bir spordur. Bu afiş çalışmasında saat görselinin zaman kavramını çağrıştırması ve zaman kavramına vurgu yapılması açısından doğru bir seçim olduğunu söyleyebiliriz. Tenis-saat kavramlarının birlikte ele alınması afiş görselinde yananlam olarak tüketicilere zaman kavramına verilen önemin kavranması açısından da çağrışımlar yansıtmaktadır.

İki numaralı görselde alan araştırması katılımcıları en çok raket objesine dikkat etmişlerdir. Raket, yananlam olarak profesyonellik ve en iyi duruş, en ideal olan araç ve başarı çağrışımlarını yapmaktadır. Dolayısıyla "tenis oynarken başarıyı sağlayan araç nasıl ki raket ise, zamanı yönetirken en ideal ve profesyonel olan marka da Rolex'dir" mesajı vermektedir diyebiliriz.

Üçüncü reklam afişinde en dikkat çeken obje kupa olarak seçilmiştir. Kupa'nın yananlam olarak çağrışımları ise Grand Slam kupasını en çok kazana kişinin Roger Federer olması ve kupanın tam olarak kazanma kavramını çağrıştırması açısından oldukça önemlidir. Böylece, tüketicilere "Rolex markasını kullanarak en büyük ve önemli kupaları kazanmış kadar başarıyı deneyimleyebilirsiniz" çağrışımı aktarılmaktadır.

Sonuç olarak her iki inceleme ve analiz yönteminin bulguları harmanlandığında, Rolex-Roger Federer reklam afişleriyle ilgili açık uçlu olarak yöneltilen sorulara verilen cevaplar ile göstergebilimsel analizde elde edilen çağrışımların doğru orantılı olduğunu söyleyebiliriz. Dolayısıyla, reklam yüzleri ve reklam görselleri ile marka imajı ve itibarı arasında da doğru orantılı bir mesaj aktarımı olduğu sonucuna varabiliriz.

\section{Sonuç ve Değerlendirme}

Markalar, iletişim çalışmalarındaki görsellerde kullandıkları unsurlar ya da dizaynların yanı sıra ünlüleri de kullanarak belli bir statü algısı ve satın almaya yönlendiren referans kişi yönlendirimi gerçekleştirmektedirler. Ancak yapılan reklam çalışmalarında görsel kalite ve ünlünün kendi algısının doğrudan tüketiciyi etkilediği gerçeğini daima ön planda tutarak, marka ve ürüne yönelik mesajların göstergebilimsel unsurlar ve göndermelerle bezeli mesajlarını da dikkate almaları gerekmektedir. Bu 
çalışmada Roger Federer ve Rolex markası ikilisinin yer aldığı reklam görsellerinin grafik dizaynlarına ilişkin göstergebilimsel inceleme sonucunda elde edilen değerlendirmelerle, aynı görsellere alan araştırması ile yöneltilen sorulara tüketicilerin verdikleri yanıtlar bu bulguyu destekler niteliktedir.

"Dijital Ortamda Marka İmaj Transferi ve İtibar Göstergelerinin Rolex - Roger Federer Örneği”" üzerinden incelendiği bu çalışmada sonuç olarak aşağıdaki değerlendirmelerin dikkate alınması gerektiğini söyleyebiliriz:

Her reklam çalışmasında marka vaadinin, marka yüzü olan ünlüyle aynı doğrultuda mesajlar içermesi gerekmektedir. Markanın reklam yüzü olan ünlünün imajı, itibarı ve tanınırlı̆̆ı ile reklama konu olan ürünün imajı, itibarı ve tanınırlı̆̆ı birbiriyle etkileşim içerisindedir. Markaların imaj transferi yaparken seçtikleri ünlüler, markanın felsefesi, vizyonu ve değerleri ile doğru orantılı olmalıdır. Rolex markası bu anlamda İsviçre kökenli bir marka olması nedeniyle İsviçreli bir sporcuyu; elit bir ürün olması sebebiyle aristokrasin ve yüksek gelir grubunun ilgi gösterdiği bir spor dalının temsilcisini seçmiştir. Ayrıca kullandığı ünlüyü de görsellerde bu mesajlarına destek olacak şekilde giyim, renk ve aksesuarlarla birlikte kullanmıştır.

Markanın logo tasarımı ve renkleri dahil her türlü göstergebilimsel detayı, hitap edilen hedef kitlenin algılarına yönelik olarak göstergebilimsel detaylarla dikkat edilerek oluşturulmuştur. Rolex'in altın rengi taç figürlü logosu, yeşil renk, Federer'e sponsor olan diğer markaların da yüksek gelir grubu tüketicilere hitap eden markalar olması gibi detaylar, reklam görsellerinin belli bir hedef kitlenin satın alma kadrajına girmesini, diğer hedef kitlelerin de istek ve beklenti içine girmesini sağlamaktadır diyebiliriz.

Bir markanın itibar algısını oluşturan unsurların göstergebilimsel sembollerinin kullanılan reklamlardaki diğer tüm detaylarla örtüşmesi, özel bir çalışma ve dikkat gerektirmesinin yanı sıra, markanın itibarlı olarak algılanmasındaki kabulü de kolaylaştıran yaygın bir mesaj ortamı sağlamaktadır. Günümüzde dijital ortamlarda kullanılan reklam görselleri ile geleneksel mecralardaki reklam görselleri aynı tutularak “ortak mesaj ve imaj” algısı yaratılmaktadır. Ancak dijital ortamlardaki mesajların kişiye özel kanal ve ortamlarla direkt tüketicilere ulaşmasındaki kolaylık ve hızlı yayılım, dijital ortamlarda kullanılacak reklamların görsellerine büyüterek odaklanmakta daha elverişli koşulların olması, tüketicilerin görsel çalışmalara daha fazla dikkat vermesine neden olmaktadır. $\mathrm{Bu}$ nedenle dijital reklamlardaki göstergebilimsel detaylar daha önem kazanırken, geleneksel reklam mecralarındaki reklam görsellerinin daha genel algıya yönelik mesajlar içermesi bir anlamda iki mecranın reklam görsellerinin içerik olarak farklı bakış açılarına ancak ortak mesaja hitap ederek hazırlanması daha geçerli olacaktır diyebiliriz.

Marka itibarı, markaya ilişkin gerçekleştirilen tüm çalışmalarla birlikte ele alınması gereken, uzun süreli ve kesintisiz iletişim süreçleriyle oluşturulan, kurumsal itibar unsurları ve markanın algısal değerlerinin örtüştüğü çalışmalarla tüm hedef kitlelere aktarılan çabaları kapsamaktadır.

Rolex ve Roger Federer örneğinde bütün bu özdeşleşmeler görülmektedir. Rolex, markanın vaadi olan extrem ürünler, yenilikçi yaklaşımlar, inovatif unsurlar, coğrafi menşei, kalite, seçkinlik, güven, başarı, güzellik, zafer, dünyaca tanınmışlık, zor çabalarla halk edilen ürüne erişim gibi unsurları Roger Federer'in sporcu kimliği, özel hayatının kalitesi, dünyaca ses getiren başarıları, İsviçreli olması, tanınırlığ1, yakışıklılığı, özel hayatına verdiği önem, tarzı, stili ve hayat felsefesinin özgünlüğü gibi unsurlarla görsel, dilsel ve imaj olarak bütünleştirmektedir.

$\mathrm{Bu}$ çalışmada ele alınan göstergebilimsel inceleme ve alan araştırmasındaki bulgular, daha geniş boyutlarla marka-imaj transferi-itibar göstergeleri konularında araştırmalar yapılarak konun incelenmesi gerekliliğini ortaya koymaktadır. Ayrıca markaların iletişim çalışmalarında daha çok bilimsel ve stratejik unsurların yer aldığı uygulamalara yönelmelerinin, günümüz dijital ortamlarında tüketicilerle bütünleşme eğilimlerinin bir sonucu olduğu açıkça ortaya çıkmaktadır. Çünkü, yeni tüketici anlayışında yalnızca somut faydaların değil, soyut ve değerlere yönelik imaj ve itibar unsurlarının da etkili olduğu ve tüketicilerin haz ve satın alma faaliyetinden doyum ile ilgili daha çok duygusal motivasyonu dikkate aldığı bir gerçektir. Ünlüler, tanınmış kişiler ve onların imajları ve mesajları da somut ve duygusal olarak 
hem markaların algılarında hem de tüm tüketicilerin kalplerinde ve zihinlerinde mutlaka bir yer kaplamaktadırlar.

\section{Kaynakça}

Aaker, D. A. (1991). Managing Brand Equity. New York: The Free Press.

Akdu, S., (2017). Compensation Strategies for Service Deficits in Tourism Sector, A Research on Perception of Service Quality and its relationship with Perception of Corporate Image, Unpublished PhD Dissertation, Gümüşhane, Gümüşhane University, Institute of Social Sciences.

Barthes, R., (1979). Göstergebilim Illkeleri. Çev. B. Vardar \& M. Rifat. Kültür Bakanlı̆̆1 Yayınları, Onay:23 Mayıs 1979/831.0-711 sayı. Birinci Baskı, Metaksan Ltd Şti: Ankara.

Bearden, W. O., \& Etzel, M. J. (1982). Reference Group Influence On Product And Brand Purchase Decisions. Journal Of Consumer Research, 9, 183-194. Http://Dx.Doi.Org/10.1086/208911.

Bircan, U. (2015). "Roland Barthes ve Göstergebilim". Sosyal Bilimler Araştırma Dergisi, Cilt:13, Say1:26, 17-41.

Dobni, D., \& Zinkhan, G. M. (1990). In Search Of Brand Image: A Foundation Analysis. Advances In Consumer Research, 17(1), 110-119.

Fiske, J., (2003) İletişim Çalışmalarına Giriş. Çev. Süleyman İrvan. 2. Basım. Bilim ve Sanat Yayınları: Ankara.

Hatch, M. J. and Schultz, M. (1997). "Relations Between, Organizational Culture, Identity and Image" European Journal of Marketing, Vol: 31, 5/6, 356-357.

Karaköse, T. (2007). DNA, Reputation and Management Enterprises, Nobel Publications, Ankara.

Keller, K.L. (1993). Conceptualizing, Measuring, and Managing Customer-Based Brand Equity. Journal of Marketing, 57, 1-22. http://dx.doi.org/10.2307/1252054.

Keller, K.L. (2003). Brand Synthesis: The Multidimensionality of Consumer Knowledge. Journal of Consumer Research, 29, 595-600. http://dx.doi.org/10.1086/346254.

Koçak, S. (2018) Kurumsal İletişim Unsurlarıyla İtibar Yönetimi, Der Yayınları:İstanbul.

Mudambi, S. M., Doyle, P. \& Wong, V. (1997). An Exploration of Branding in Industrial Markets. Industrial Marketing Management, 26(5), 433-446.

Shockley-Zalabak, P. Ellis K. and G. Winograd (2000). Organizational Trust: What It Means, Why It Matters, Organization Development Journal, Vol 18:4.

Yaşlığlu, M. M., (2012). A Model Proposal to Measure Corporate Reputation and Perception of Corporate Reputation in Companies, Application in Automotive Sector, Unpublished $\mathrm{PhD}$ Dissertation, İstanbul, İstanbul University, Institute of Social Sciences.

Foger Federer Reklamı 1, http://chronoscope.ru/2011/05/lords-of-the-balls/, Erişim Tarihi 04.07.2020.

Foger Federer Reklamı 2, https://www.ebay.ca/itm/Publicite-advertising-2010-La-Montre-Rolex-OysterPerpetual-avec-Roger-Federer-/3221052455797, Erişim Tarihi 04.07.2020.

Foger Federer Reklamı 3, https://cofounderstown.com/rolex-doesnt-just-show-time-teaches-cbe96, Erişim Tarihi 04.07.2020.

Foger Federer Reklamı 4, https://www.oversmartwatch.com/5-more-remarkable-rolex-ads-from-daysgone-by/, Erișim Tarihi: 04.07.2020. 
https://www.rolex.com/tr/about-rolex-watches/2013-2019.html, Erişim Tarihi: 20.07.2020.

https://paratic.com/rolex-hakkindaki-sasirtici-bilgiler/, Erişim Tarihi: 20.07.2020.

https://www.milliyet.com.tr/ekonomi/sponsor-canavari-milyonluk-raketler-2180025, Erişim Tarihi 21.07.2020.

https://www.haberler.com/roger-federer/biyografisi/, Erişim Tarihi:21.07.2020. 